\title{
How DOES EXTERNAL DEBT SERVICING ABILITY AFFECT THE STABILITY OF ELECTOR- AL AUTHORITARIAN REGIMES? ${ }^{\mathrm{T}}$
}

FUR, VIOLA ${ }^{2}$

"You SHOUld NEVER ASK ANYONE FOR ANYTHING. NEVER - AND ESPECIALLY FROM THOSE WHO ARE MORE POWERFUL THAN YOURSELF" Mikhail Bulgakov

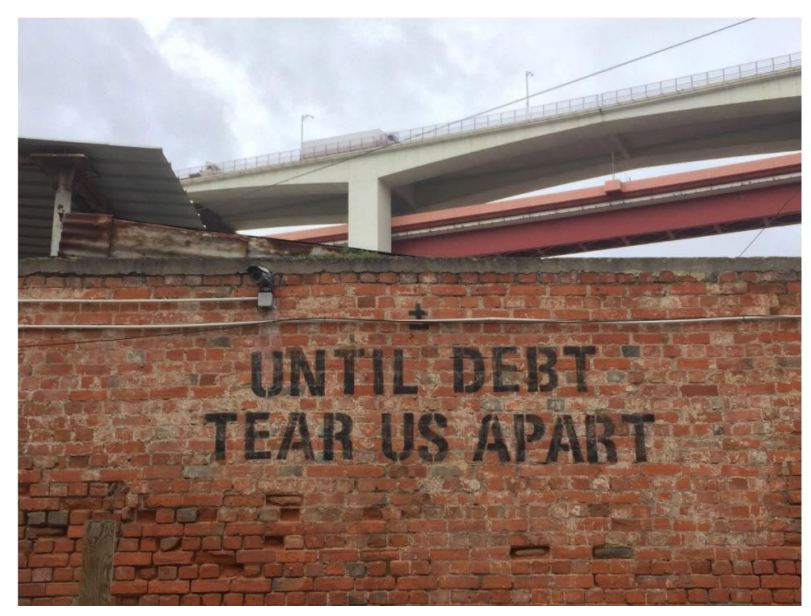

"SOMETIMES I THINK THAT A PARODY OF A DEMOCRACY COULD BE MORE DANGEROUS THAN A BLATANT DICTATORSHIP, BECAUSE IT GIVES PEOPLE AN OPPORTUNITY TO AVOID DOING ANYTHING ABOUT IT"

Aung SAn SuU Kyi

\footnotetext{
${ }^{1}$ This work is licensed under CC BY 4.0. To view a copy of this license, visit https://creativecommons. org/licenses/by/4.0

${ }^{2}$ Viola Fur is a Senegal-based Associate at IDinsight, an advisory, data analytics, and research organization fighting poverty worldwide. She is a recent graduate of the University of Oxford, where she studied Philosophy, Politics and Economics and graduated with First Class Honours. She specializes in the political economy of development in Sub-Saharan Africa.
} 


\section{INTRODUCTION}

Of all the places former Gambian President Dawda Jawara had expected to be on the evening of July 22, 1994, the US tank landing ship La Moure County bound for Senegal was likely not one of them. Yet that morning he had been ousted in a military coup led by then-Lieutenant Yahya Jammeh, ending Jawara's twenty four years of electoral authoritarian rule.

Of all the things 2016 Gambian presidential candidate Adama Barrow had foreseen saying to the BBC on December 2, 2016, the sentences 'I am very, very, very happy. I'm excited that we won this election' were likely not among them. ${ }^{3}$ He had run against now-Colonel Yahya Jammeh, who had led The Gambia for twenty two years after his coup. In a "remarkable upset victory," the opposition candidate triumphed. ${ }^{4}$

Electoral authoritarianism is a widespread method of governance that is distinct from both authoritarianism and democracy. Variously called 'competitive authoritarianism' or 'hybrid regimes,' these are regimes that rely on legitimation, repression, and co-optation as they combine nominally democratic institutions with authoritarian practices. ${ }^{5},{ }^{6}$ In essentially all countries, heads of state come to power via competitive elections held under universal suffrage at regular intervals. They win office - and then some win office again, and again, and again. The puzzle of electoral authoritarianism is how this is possible. Why is it that Hun Sen, President of Cambodia, has gotten re-elected five times to date, serving continuously since 1997? Why is it that Paul Kagame, President of Rwanda, has served three seven-year terms to date, ruling the country continuously since 2000? But why is it also that Robert Mugabe, who had ruled Zimbabwe since 1980 , was ousted in a coup in 2017?

In an attempt to explain the causes of electoral authoritarian stability,

\footnotetext{
3 "Gambia's Jammeh Loses to Adama Barrow in Shock Election Result," BBC News, BBC, December 2, 2016, www.bbc.co.uk/news/world-africa-38183906

4 Sheriff Kora and Momodou N. Darboe, "The Gambia's Electoral Earthquake," Journal of Democracy, 28.2 (2017): 147, https://doi.org/10.1353/jod.2017.0031

5 Johannes Gerschewski, "The Three Pillars of Stability: Legitimation, Repression, and CoOptation in Autocratic Regimes," Democratization, 20.1 (2013): 13, https://doi.org/10.1080 /13510347.2013.738860

${ }^{6}$ Marc Morjé Howard and Philip G. Roessler, "Liberalizing Electoral Outcomes in Competitive Authoritarian Regimes,” American Journal of Political Science, 50.2 (2006): 365-366, https://www.jstor.org/stable/3694278
} 
the literature has looked to explanations rooted in domestic institutions. This is not surprising given that Svolik finds that two-thirds of electoral authoritarian collapses are explained by a coup d'état, meaning it is important to study domestic, intra-elite dynamics. ${ }^{7}$ Models such as that of Boix and Svolik have placed emphasis on the ways in which formal political institutions, such as political parties and legislatures, may lead to greater regime stability. ${ }^{8}$ Powersharing is characterized by a "moral hazard problem" whereby the electoral authoritarian incumbent seeks more power at the expense of the ruling coalition. ${ }^{9}$ However, elites' primary weapon, coups, are "imperfect" as the only deterrent to this threat. ${ }^{10}$ Therefore, establishing institutions can "alleviate the moral hazard problem." 11 This is because these institutions ensure regular interaction between the incumbent and their allies and foster transparency in decision-making bodies. ${ }^{12}$ Therefore, electoral authoritarian stability and collapse are explained by the strength of nominally democratic institutions and the intra-elite interactions they facilitate.

However, electoral authoritarian states' elites do not exist in a vacuum. Research by Whitehead and others has explored how international actors, such as the US, can influence democratization and regime outcomes. ${ }^{13}$ More recently, the literature on failed democratization, and by extension on electoral authoritarian regimes, has found that the world is experiencing what Nicolas van de Walle calls 'democracy fatigue,' whereby international actors since 2000 have not promoted democratization and good governance with the same intensity as in the 1990s. ${ }^{14}$ While the mechanism through which these abstract norms affect

\footnotetext{
${ }^{7}$ Milan Svolik, „Power-Sharing and Leadership Dynamics in Authoritarian Regimes,” SSRN Electronic Journal (2008): 478, https://www.jstor.org/stable/25548130

${ }^{8}$ Carles Boix and Milan W. Svolik, "The Foundations of Limited Authoritarian Government: Institutions, Commitment, and Power-Sharing in Dictatorships," The Journal of Politics, 75.2 (April 2013): 301, https://doi.org/10.1017/S0022381613000029

9 Svolik, "Power-Sharing and Leadership Dynamics in Authoritarian Regimes," 492.

${ }^{10}$ Ibid., 492.

${ }^{11}$ Ibid., 492.

${ }^{12}$ Boix and Slovik, "The Foundations of Limited Authoritarian Government," 301.

${ }^{13}$ See, for example: Laurence Whitehead, The International Dimensions of Democratization: Europe and the Americas, 2nd ed (Oxford, GBR: Oxford University Press, 2001); and Scott Mainwaring and Aníbal S. Pérez Liñan, Democracies and Dictatorships in Latin America: Emergence, Survival, and Fall, (New York, NY: Cambridge University Press, 2013).

${ }_{14}$ Nicolas van de Walle, „Conclusion: democracy fatigue and the ghost of modernization theory," in Aid and Authoritarianism in Africa: Development without Democracy, ed. by Tobias
} 
electoral authoritarian leaders, elites and their populations is not well-established, international factors nonetheless influence domestic agents and therefore regime stability.

Although the literature has examined how general international factors influence regime outcomes, international political economic factors, and their relationship with electoral authoritarian regimes as opposed to democratization, has been largely neglected. Indeed, Svolik briefly posits that an 'endogenously evolving balance of power' determines the credibility of a coup threat, ${ }^{15}$ but what actually affects the balance of power between the incumbent and the elite? How are we to understand the linkages between elites and the general population in cases when elites are elected party leaders who are, at least nominally, responsive to the population? Domestic agents' decisions are shaped by the international political economy; while the effects of aid on regime type have been explored, ${ }^{16}$ other factors had not been analyzed until recently. ${ }^{17}$ Debt, in particular, received some academic attention in the discussions surrounding the Structural Adjustment Programs in the 1980s and 1990s, ${ }^{18}$ whereby international financial institutions such as the World Bank and the International Monetary Fund provided loans to developing countries. Since then, however, it has been academically underexplored.

This article attempts to bridge the gap between debt as an international political economic factor affecting domestic agents' incentives, and the stability of electoral authoritarian regimes. The article's argument is as follows. In the first stage, the US interest rate, as set by the Federal Reserve, can rise; alternatively, the commodity index can rise. These shocks are exogenous to the electoral authoritarian state, meaning that the changes occur independently of the state's actions. In the second stage, the percentage of public and publicly guaranteed (PPG) debt that is denominated in USD will rise; and the percentage of GDP represented by commodity rents, or payments from commodity sales, will also

Hagmann and Filip Reyntjens (Uppsala, Sweden: Nordiska Afrikainstitutet; London, Zed Books, 2016).

${ }^{15}$ Svolik, "Power-Sharing and Leadership Dynamics in Authoritarian Regimes,"492.

${ }^{16}$ See, for example: Tobias Hagmann and Filip Reyntjens, Aid and Authoritarianism in Africa: Development without Democracy, (Uppsala, Sweden: Nordiska Afrikainstitutet; London, Zed Books, 2016).

${ }^{17}$ Oisín Tansey. The International Politics of Authoritarian Rule, (Oxford: Oxford University Press, 2016): 23.

${ }^{18}$ See, for example: Thomas Callaghy, "Africa’s Debt Crisis." Journal of International Affairs, 38.1 (1984): 61-79. 
rise. These two changes signal a decline in external debt servicing ability. In the third stage, the electoral authoritarian leader will need to change the level of government expenditure to meet the country's debt repayment obligations whilst also trying to maintain the co-optation of elites through rent distribution amidst economic hardship. In the fourth and final stage, in response to this change in government expenditure, elites will perceive potential rent distribution as a signal of incumbent instability or austerity policies that would elicit discontent from elites and the general population. As a result, electoral authoritarian collapse, either elite-led or popular mobilization-induced, will occur.

The empirical section tests this argument and its three steps using quantitative, large- $\mathrm{N}$ analysis. The data on electoral authoritarian collapse and the types of collapse comes from the Geddes, Wright and Frantz Autocratic Regimes dataset. The years 1960 - 2010, and the 193 UN member states, are considered in the analysis. The empirical section will also explore heterogeneity within the mechanism, analyzing how different changes in government expenditure are likely to lead to different forms of electoral authoritarian collapse with agency on the part of different sections of the population. In general, electoral authoritarian collapse is predicted by a rise in the percentage of USD-denominated debt, a rise in the percentage of GDP that commodity rents comprise, and a change in government expenditure as a percentage of GDP.

The analysis will be applied to a case study examining The Gambia, a West African country that experienced two instances of electoral authoritarian collapse. First, on July 22, 1994, a staged military coup, linked to a change in government expenditure, signaled the electoral authoritarian incumbent's instability. On December 1, 2016, the electoral authoritarian incumbent of twenty two years was defeated in the presidential elections, largely as a result of the rise in USD-denominated debt and commodity rents as a percentage of GDP due to an exogenous economic shock. This case study will allow for the heterogeneity in the argument to be observed in practice.

In the first section, the theoretical background for the argument and its three steps will be developed. Next, the empirical analysis will be presented, exploring both the model as a whole and the heterogeneity within it. The penultimate section applies the theoretical and empirical analysis to examine a case study of two instances of electoral authoritarian collapse in The Gambia. The final section concludes by linking the analysis to the literature and future 
avenues of research.

\section{THEORY}

Electoral authoritarian regimes have proven to be remarkably resilient since their emergence in the second half of the 20th century, but international political economic factors as causes of their stability have been largely underexplored by the literature. Yet intuitively, it would make sense that international political economic factors, and specifically debt, matter. A country having some level of debt poses no complications so long as the interest rate is lower than the GDP growth rate, so that governments can make future taxpayers repay any outstanding debt. ${ }^{19}$ Sovereign debt, however, deserves particular attention. It is defined as debt issued by a national government that is denominated in a foreign currency. ${ }^{20}$ The 'foreign currency' component is crucial, because it means debt repayment will not be determined exclusively by the debtor country, but by exogenous factors as well. If a country cannot service its sovereign debt, that can cause complications regardless of regime type. Specifically, creditor governments or organizations face increasing incentives to intervene in the debtor country's domestic affairs, for example by pressuring private lenders to make concessions to debtors. ${ }^{21}$ This occurred, for instance, during the East Asian financial crisis of 1997-8. ${ }^{22}$

A decline in debt servicing ability is particularly damning for electoral authoritarians. Incumbency allows the leader access to patronage networks, but in exchange the leader has a reciprocal duty to their patron elites. ${ }^{23}$ Therefore, a debt shock, which makes incumbents less able to service their debts, will necessitate changes in levels of government expenditure both towards elites and towards the general population. This endangers the incumbent's position, because elite mobilization, in the form of a coup or through opposition mobilization during elections, or through popular mobilization and uprisings, can oust the incumbent. Whether that change in government expenditure is the implementation of austerity

\footnotetext{
${ }^{19}$ Pierre Lemieux, The Public Debt Problem : a Comprehensive Guide, (New York, NY: Palgrave Macmillan, 2013): 15

${ }^{20}$ Lemieux, The Public Debt Problem, 3.

${ }^{21}$ Vinod K. Aggarwal and Brigitte Granville, "Introduction,” in Sovereign Debt: Origins, Crises and Restructuring, edited by Aggarwal and Granville (London: Royal Institute of International Affairs, 2003): 31 .

22 Aggarwal and Granville, "Introduction," 34.

${ }^{23}$ Nic Cheeseman, "African Elections as Vehicles for Change," Journal of Democracy, 21.4 (2010): 145-146, https://doi.org/10.1353/jod.2010.0019
} 
policies or an attempt to forestall elite unrest through a temporary increase in government expenditure is a question competing answers have been proposed to, and something that will be investigated below. Changes in debt servicing ability represent a necessary but insufficient condition for electoral authoritarian collapse, and elites can exercise their agency to bring about diverging outcomes. Still, a change in government expenditure can lead to either elite-led or popular mobilization-induced collapse.

In brief, a rise in the US interest rate or a commodity shock represents an exogenous shock to the electoral authoritarian regime. These will worsen the country's debt servicing ability, which in turn will lead to the electoral authoritarian leader altering the amount of government expenditure. In response to such a policy, electoral authoritarian collapse becomes more likely, either as the result of an elite-led process or a popular mobilization-induced one. Figure 1 illustrates this argument, each step of which is discussed in greater detail below.

Figure 1: The Argument

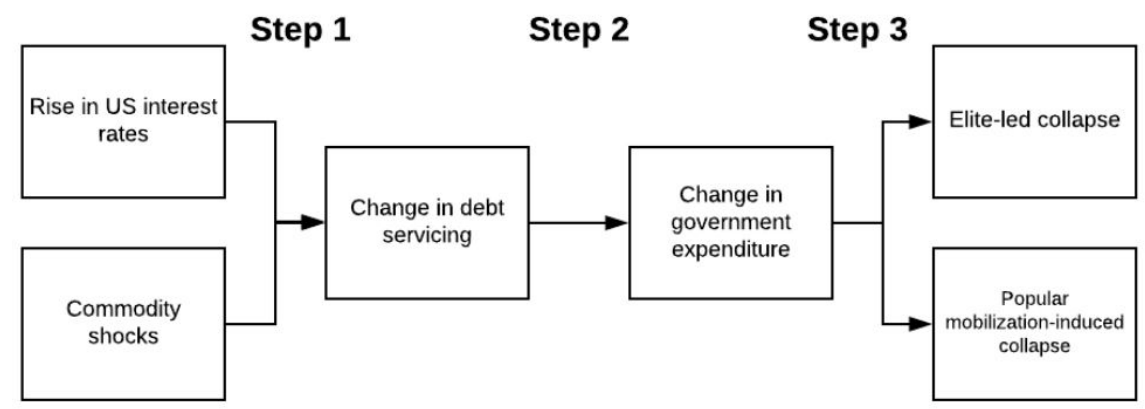

\section{Debt Shocks}

Experiencing a debt shock represents the first step of the argument illustrated on Figure 1. Most governments, democratic or not, have a significant 
amount of debt. ${ }^{24}$ However, much depends on the currency in which a country's debt is denominated; if it is denominated in a foreign currency, such as US dollars, then debt shocks can be exogenous to the debtor country. When a regime experiences a debt shock, however, the government will want to smooth the impact of disturbances. A democratic leader is incentivized to leave tax rates and government spending levels unchanged. ${ }^{25} \mathrm{~A}$ nondemocratic leader, however, already uses the provision of private goods to co-opt elites and public goods provision to co-opt the general population, and these two channels of expenditure will be at their disposal to alter when they need to service their debts. ${ }^{26}, 27$

Still, electoral authoritarians do face challenges in servicing their external debt. In particular, two shocks will be considered that make debt servicing more challenging. The first is a rise in the United States Federal Reserve interest rate, and the second is a commodity shock. Highlighting these two factors is in line with Campello and Zucco's analysis of how commodity price fluctuations and US interest rate changes affect Latin America. ${ }^{28}$ They contend that these factors will make Latin American democratic countries more likely to implement procyclical fiscal policy ${ }^{29}$, while this analysis focuses on how a change in US interest rates and commodity prices affects debt servicing in electoral authoritarian states worldwide.

\section{Federal Reserve Interest Rates}

Most countries, electoral authoritarian states included, tend not to borrow in their own currency; instead, the US dollar is the most common currency denomination for external debt. ${ }^{30}$ The Federal Reserve sets the interest rate exogenously to electoral authoritarian countries' debt dynamics. This means that increasing the interest rate of the currency in which a country's debt is denominated

${ }^{24}$ Graeme Wheeler, Sound Practice in Government Debt Management (The World Bank Group: World Bank Publications, 2004): 6.

${ }^{25}$ Wheeler, Sound Practice, 80.

${ }^{26}$ Jennifer Gandhi, Political Institutions under Dictatorship, (Cambridge, England: Cambridge University Press, 2008): 110.

${ }^{27}$ Gandhi, Political Institutions, 111.

${ }^{28}$ Daniela Campello and Cesar Zucco, „Presidential Success and the World Economy,” The Journal of Politics 78.2 (2016): 589, https://doi.org/10.1086/684749.

${ }^{29}$ Daniela Campello, "The Politics of Financial Booms and Crises: Evidence from Latin America," Comparative Political Studies, 47.2 (2014): 268, https://doi.org/10.1177/0010414013488539

${ }^{30} \mathrm{H}$. Ito and C.M. Rodriguez "Clamoring for Greenbacks: Explaining the Resurgence of the U.S. Dollar in International Debt," International Finance (2020): 2, https://doi.org/10.1111/infi.12370 
will lead to an increase in that country's external debt. ${ }^{31}$ For instance, when the Federal Reserve increased its interest rate in 1979, debtor countries were not only able to borrow less, but they also owed larger interests on their pre-existing loans, thereby making them less able to service their debt. ${ }^{32}$ This credit squeeze affected Latin American and Sub-Saharan African authoritarian states adversely, pushing many to a debt crisis, necessitating them to alter government expenditure rates. ${ }^{33}$

\section{Commodity Shocks}

Commodity prices constantly fluctuate, leading to commodity shocks, whereby the price of a given commodity changes significantly within a short period of time. ${ }^{34}$ Specifically, if a country is reliant on exports and the global price of the key exported commodity falls, the extent to which it can service its debt will also decrease. ${ }^{35}$ Consequently, it might need to increase its debt as a response to the current account deficit. For example, during the global decline in oil prices in 1998, oil exporters like Russia and Indonesia entered a debt crisis. ${ }^{36}$ Conversely, a global boom in exported commodity prices can give the electoral authoritarian state further revenues to fuel its patronage systems. ${ }^{37}$ For example, Tansey claims this happened following the global rise in oil prices in the early 1980s, after which the Mexican electoral authoritarian party PRI could increase its expenditure towards elites and the general population. ${ }^{38}$ Similarly, Weyland argues that electoral authoritarians Hugo Chávez and Evo Morales "entrenched

\footnotetext{
${ }^{31}$ Sebastian Edwards and Felipe B. Larrain, eds., Debt, Adjustment and Recovery : Latin America's Prospects for Growth and Development, (Oxford, UK: Basil Blackwell, 1989): 58.

${ }^{32}$ Fantu Cheru, "Playing Games with African Lives: The G7 Debt Relief Strategy and the Politics of Indifference," in Sovereign Debt at the Crossroads: Challenges and Proposals for Resolving the Third World Debt Crisis, ed. Chris Jochnick and Fraser A. Preston (New York: Oxford University Press, 2006): 38.

${ }^{33}$ Cheru, "Playing Games with African Lives," 38.

${ }^{34}$ Takatoshi Ito and Andrew Rose, Commodity Prices and Markets, (Chicago, IL: University of Chicago Press, 2011): 1.

${ }^{35}$ Rabah Arezki, Marc Quintyn, Catherine A. Pattillo, and Min Zhu, eds. Commodity Price Volatility and Inclusive Growth in Low-Income Countries. International Monetary Fund (Washington D.C.: IMF, 2012): 22.

${ }^{36}$ Arezki et al, Commodity Price Volatility, 22.

37 Kurt Gerhard Weyland, "The Threat from the Populist Left," Journal of Democracy, 24.3 (2013): 28-32, https://doi.org/10.1353/jod.2013.0045.

${ }^{38}$ Tansey, The International Politics of Authoritarian Rule, 44.
} 
their rule" due to a commodity boom. ${ }^{39}$ Therefore, if a commodity exporter experiences a commodity shock such that global commodity prices fall relative to their former values, it will have fewer resources to spend on patronage. Additionally, as it becomes less able to service its rising debt, the electoral authoritarian state will have to change its levels of government expenditure.

\section{Changing Government Expenditure}

A change in government expenditure corresponds to step 2 in Figure 1. Facing a decline in budgets, either as a result of a rise in the Federal Reserve interest rate or a commodity shock, it is intuitively thought that the electoral authoritarian incumbent will need to implement austerity policies. The resource constraint can tighten through two main channels: reducing government spending or reducing private spending, such as through tax rises. ${ }^{40}$ This austerity can be directed both at elites (by cutting back on patronage) or at the general population (through conventional austere economic policy). It is hypothesized that both groups will experience cutbacks in government spending as a result of a decline in debt servicing; there is agency on the part of the electoral authoritarian leader to decide who their austerity policies will target, and to what extent. However, previous research has also suggested that the relationship between austerity and electoral authoritarian collapse is not linear and heterogeneous effects can hold. Gandhi and Przeworski hypothesize that governments can attempt to keep elites on their side following a debt shock by temporarily making greater policy concessions, such as increasing government expenditure. ${ }^{41}$ However, this sends a signal of instability to the elites, which can incentivize them to overthrow the incumbent. These seemingly counterintuitive but in reality complementing hypotheses will be explored further.

Before looking at how elites and the general population will be affected by a change in government expenditure, it is important to consider the question of debt default. After all, one could argue, electoral authoritarian incumbents could simply default on their debt. This would curtail the potentially harmful effects of changing the level of government expenditure. However, they typically do not

\footnotetext{
${ }^{39}$ Weyland, "The Threat from the Populist Left," 32.

${ }^{40}$ Anthony Barnes Atkinson, Public Economics in an Age of Austerity, (New York, NY: Routledge, 2014): 6 .

41 Jennifer Gandhi and Adam Przeworski, "Cooperation, Cooptation, and Rebellion Under Dictatorships.” Economics \& Politics, 18.1 (2006): 1, https://doi.org/10.1111/j.14680343.2006.00160.x
} 
pursue this option in order to preserve legitimacy and avoid the potential danger of foreign involvement.

Legitimacy, and the desire for legitimation, are essential for electoral authoritarian states. After the end of the Cold War, some countries instituted multiparty elections as a result of donor conditionality. ${ }^{42}$ Maintaining a democratic, legitimate façade, however thin, is therefore essential for electoral authoritarian regimes. Grauvogel and von Soest argue that authoritarians seek legitimacy across six dimensions: ideology, foundational myth, personalism, international engagement, procedural mechanisms, and performance.. ${ }^{43}$ They are aided in this process by the international community: after the international community began its sometimes uneven efforts to promote democratic norms in the 1990s, this trend changed and international actors no longer promote democracy with the same intensity. ${ }^{44}$ This 'democratic fatigue' means that electoral authoritarians can cling to ideological and international legitimacy with greater ease. Nonetheless, economic performance legitimacy remains important to retain. A sovereign debt crisis would lead to a decline in legitimacy, both globally, but more importantly domestically, making the incumbent vulnerable to being overthrown. Instead, it is hypothesized that when a regime is less able to service its sovereign debt, the incumbent will not default on that debt due to a danger of decline in legitimacy.

An additional reason why the incumbent will not default on their debt is that doing so would lead to foreign involvement in their economy, destabilizing the authoritarian regime. Kaplan argues that in response to the Latin American debt crisis, a structural adjustment program was implemented, which in turn diminished political control over the economy. ${ }^{45}$ Specifically, the forced shift to the decentralized bond market from centralized bank lending meant that

\footnotetext{
42 Barbara Geddes, Joseph Wright and Erica Frantz, How Dictatorships Work: Power, Personalization, and Collapse, Cambridge, UK: Cambridge University Press, 2018): 138.

${ }^{43}$ Julia Grauvogel and Christian Von Soest, "Claims to Legitimacy Count: Why Sanctions Fail to Instigate Democratisation in Authoritarian Regimes," European Journal of Political Research, 53.4 (2014): 638, https://doi.org/10.1111/1475-6765.12065

${ }_{44}$ Tobias Hagmann and Filip Reyntjens, "Introduction: aid and authoritarianism in sub-Saharan Africa after 1990," in Aid and Authoritarianism in Africa : Development without Democracy (London, GBR: Zed Books 2016) 15.

45 Stephen B. Kaplan, Globalization and Austerity Politics in Latin America, (New York, NY: Cambridge University Press, 2013): 37.
} 
the exit threat lenders could exert intensified, which in turn imposed economic discipline and responsibility on the countries' governments. ${ }^{46}$ More generally, in response to debt crises the US has led international bailout initiatives that affected countries' domestic economies, such as its interventions in the Mexican economy during the Mexican peso crisis of $1994 .{ }^{47}$ As a result, electoral authoritarian states have attempted to avoid defaulting on their debt, because doing so would lead to structural reform or other forms of economic intervention, both of which would significantly and immediately undermine their rule. Occasionally, it can be inevitable for a country to default on its debt when it experiences an overwhelmingly negative debt shock, as has been the case during the ongoing Crisis in Venezuela (2016 - ), but barring a shock of such magnitudes, electoral authoritarian states will avoid defaulting on their debt.

Given that the electoral authoritarian leader faces strong incentives not to default on their debt, they will alter the level of government expenditure, and they will need to make a conscious decision about who to target and in what way. They can either implement austerity policies, or in an attempt to forestall elite unrest, they can temporarily raise government expenditure. Austerity policies, if implemented, can include changes in public goods' provisions, in the amount of funds transferred to elites and other nepotistic linkages. By the nature of electoral authoritarian elites, measuring some changes in government expenditure can be challenging. So instead, it is posited that there is some theoretical threshold beyond which austerity policies, as discussed in the next section, will lead to electoral authoritarian collapse. These policies must represent a substantial decrease in general government expenditure, so that their effects become particularly damning towards the electoral authoritarian incumbent. Geddes, Wright and Frantz contend that there are key patron-client relationships whose integrity is essential to the survival of the regime. Therefore when experiencing a unit size debt shock, one electoral authoritarian regime might collapse but another might survive if it upholds the patron-client relationships essential to the regime's survival. ${ }^{48}$ The empirical implications of this point will be further expounded in the data analysis section.

In certain cases, government expenditure can also temporarily rise in response to a debt shock, as the electoral authoritarian leader attempts to forestall

\footnotetext{
${ }^{46}$ Kaplan, Globalization and Austerity Politics, 9.

${ }^{47}$ Aggarwal and Granville, "Introduction," 23.

${ }^{48}$ Geddes, Wright and Frantz, How Dictatorships Work, 187.
} 
elite-led collapse. Gandhi and Przeworski have posited that the two main forms of 'carrots' at an electoral authoritarian leader's disposal are policy concessions and rent distribution. ${ }^{49}$ The latter indicates that the distribution of state resources, as Boix and Svolik's model also posits, is crucial for a regime to maintain elite support. ${ }^{50}$ Therefore, it is possible that a sharp economic crisis arising due to a decline in debt servicing could actually incentivize electoral authoritarian leaders to increase rent distribution, an anti-austerity policy. Still, in response to this, elites who have access to information about the state of the economy through the transparency of institutions might correctly perceive the instability of the electoral authoritarian leader. This in turn would make them more likely to initiate electoral authoritarian collapse. In other words, the literature identifies that government expenditure plays a key role in shaping electoral authoritarian collapse, but two slightly diverging hypotheses are presented. It is the case either that in response to a decline in debt servicing, the leader will implement traditional austerity policies, or that they will increase rent distribution in an attempt to maintain elites' support. These two hypotheses need not be mutually exclusive, and instead represent electoral authoritarian leaders' best responses in different contexts.

In conclusion, government expenditure levels will change in response to a decline in external debt servicing ability, because the alternative, defaulting on the debt, would imminently threaten the survival of the electoral authoritarian incumbent. Instead, they will attempt to implement austerity policies or targeted rent distribution and repay their debt for as long as they can.

\section{Electoral Authoritarian Collapse}

As a result of change in government expenditure, whether that be austerity or selective rent distribution, the hypothesis is that electoral authoritarian states will be at a greater risk of collapse, as step 3 of Figure 1 illustrates. There are two potential channels through which this mechanism can unfold: elite mobilization (top-down collapse) or popular mobilization (bottom-up collapse).

\section{Elite-led Collapse}

The electoral authoritarian state is shaped by its elites. 'Elites' refers

\footnotetext{
${ }^{49}$ Gandhi and Przeworski, "Cooperation, Cooptation, and Rebellion Under Dictatorships," 1.

${ }^{50}$ Boix and Svolik, "The Foundations of Limited Authoritarian Government," 302-303.
} 
to individuals in positions of power, whether they be in the governing coalition or the opposition, as the membership of such groups often changes over time. Indeed, there is a sense in which elites are the reason electoral authoritarian states exist as a separate entity to dictatorial authoritarian states. There is a consensus among the literature that domestic-level explanations are key in shaping electoral authoritarian longevity. ${ }^{51}$ Boix and Svolik's model describing the role of institutions represents this branch of the literature. ${ }^{52}$ Finding that no dictator can rule entirely alone, and that any elites they work with might attempt to depose them, Svolik's The Politics of Authoritarian Rule argues that institutions attempt to tackle this 'problem of authoritarian power-sharing' with the implementation of institutions. ${ }^{53}$ Boix and Svolik argue that institutions that constrain leaders, such as political parties and legislatures, can in fact promote authoritarian survival..$^{54}$ This is because institutions structure interactions between the leader and their allies, such that information asymmetry and uncertainty are reduced. ${ }^{55}$ Through regular interactions in deliberative and decision-making bodies, misperceptions about the leader's compliance with the power-sharing arrangements are reduced, and the elite is co-opted..$^{56}$

Not only do institutions such as political parties ensure the stability of the regime, they also allow the elites to be co-opted through patronage. ${ }^{57}$ Institutions allow loyalty to be rewarded through pork and career advancement, which incentivizes elites, including opposition politicians, to not rebel or defect. ${ }^{58}$ This analysis is often applied to the study of Sub-Saharan African countries, with most having instituted elections and nominally democratic institutions after the end of the Cold War, but many still retaining patrimonial elements. ${ }^{59}$ Still, the phenomenon is as universal as electoral authoritarianism, and it is linked to

\footnotetext{
${ }^{51}$ Tansey, The International Politics of Authoritarian Rule, 3.

${ }^{52}$ Boix and Svolik, "The Foundations of Limited Authoritarian Government," 300.

${ }^{53}$ Milan W. Svolik, The Politics of Authoritarian Rule (Cambridge: Cambridge University Press, 2012): 2 .

${ }^{54}$ Boix and Svolik, "The Foundations of Limited Authoritarian Government," 301.

${ }^{55}$ Ibid.

${ }^{56}$ Ibid.

${ }^{57}$ Steven Levitsky and Lucan Way. Competitive Authoritarianism: Hybrid Regimes after the Cold War, (New York, NY: Cambridge University Press, 2010): 26.

${ }^{58}$ Levitsky and Way, Competitive Authoritarianism, 26.

${ }^{59}$ Linda J. Beck, "Senegal's 'Patrimonial Democrats': Incremental Reform and the Obstacles to the Consolidation of Democracy," Canadian Journal of African Studies / Revue Canadienne Des Études Africaines, 31.1 (1997): 8.
} 
government expenditure and debt in important ways.

Two principal approaches to this issue have been proposed. Firstly, it has been posited that a substantial decline in government expenditure in the immediate aftermath of a crisis will lead to electoral authoritarian collapse. For instance, Easterly finds that Haiti's debt accumulated largely to finance the government's patronage networks. ${ }^{60}$ Still, when austerity policies are implemented, the government will seek to reduce expenditure to all stakeholders, including the elites. Therefore, when there is a substantial decline in an electoral authoritarian government's ability to service its debt, this will lead t0 the implementation of austerity policies, which undermine the pork distribution mechanisms embedded in institutions, thereby destabilizing the regime. This is particularly likely to be the case when government expenditure declines substantially and suddenly. Alternatively, if the electoral authoritarian leader struggled to implement austerity policies, for instance due to a more hostile legislature or stronger institutional constraints on changing spending levels, then they may resort to raising rent distribution to the elites to maintain their support amidst the crisis. However, this will send a signal to the elites that the electoral authoritarian leader perceives their position as unstable, which can induce them to oust the leader. While the type of collapse that follows the implementation of austerity policies can either be elite-led or popular mobilization-induced, the type of collapse, if there is a temporary rise in rent distribution, will be exclusively elite-driven.

An elite-led electoral authoritarian collapse can take two forms. Either the regime can collapse as a result of a coup, or as a result of elections due to opposition mobilization. ${ }^{61}$ Geddes, Wright and Frantz argue that these two types of mobilization account for $35 \%$ and $26 \%$ instances of authoritarian collapse, respectively. ${ }^{62}$ The dynamics of these two types of collapse will now be considered in turn.

Coups are the most prevalent forms of authoritarian collapse. Geddes, Wright and Frantz define coups as events that '[oust] political leaders' and are 'carried out by military defectors from the regime'. ${ }^{63}$ This military component

${ }^{60}$ William Easterly, "How Did Heavily Indebted Poor Countries Become Heavily Indebted? Reviewing Two Decades of Debt Relief.” World Development, 30.10 (2002): 1677.

${ }^{61}$ Geddes, Wright, and Frantz, How Dictatorships Work, 179.

${ }^{62}$ Ibid.

${ }^{63}$ Ibid., 178. 
shows why coups are so prevalent: they require coordinating the fewest individuals, and members of the military have weapons." ${ }^{\prime 64}$ Of course, not all coups succeed, and even where they do, the regime that follows does not always last. ${ }^{65}$ Still, coups remain common, from the 2017 ousting of Mugabe in Zimbabwe and the 2019 ousting of Morales in Bolivia, to the failed coup against Turkey's Erdogan in 2016 and the successful one against Yemen's Hadi in 2018.

Alongside coups, cases of successful opposition mobilization are the most common in undermining electoral authoritarian regimes. Howard and Roessler call these instances 'liberalizing electoral outcomes' and argue that they will happen when an opposition coalition forms and opposition mobilization occurs, with the death of the authoritarian incumbent contributing to a lesser extent. ${ }^{66}$ What matters, they argue, is the degree to which opposition leaders and civil society groups can coordinate. ${ }^{67}$ Still, this raises the question of why opposition mobilization and coalition-building was possible in some electoral authoritarian regimes over others. Greene and Arriola's analysis of Mexico and Kenya respectively explain why this happened.

Greene argues that the reason the PRI had been the dominant party in Mexican politics for decades was that by virtue of being the incumbent party, they had a resource advantage. ${ }^{68}$ This meant that they could outspend the opposition during electoral campaigns and co-opt key leaders with patronage goods. ${ }^{69}$ After all, dominant parties can divert public funds for their partisan use, and unlike democracies, electoral authoritarian states, like Mexico for much of the 20th century, lack a professionalized bureaucracy or an electoral management body that would prevent this. ${ }^{70}$ Still, the amount of pork and repression an incumbent can provide depends on their budget; Greene argues that when the PRI faced a debt crisis and needed to privatize much of the economy to avoid bankruptcy, they lost

\footnotetext{
64ibid., 180.

65 Patrick J. McGowan, “ African Military Coups D’etat, 19562001: Frequency, Trends and Distribution.” The Journal of Modern African Studies, 41.3, (2003): 339, https://www.jstor.org/ stable/3876235.

${ }^{66}$ Howard and Roessler, "Liberalizing Electoral Outcomes in Competitive Authoritarian Regimes," 371-372.

${ }^{67}$ Ibid., 371.

${ }^{68}$ Kenneth F. Greene. Why Dominant Parties Lose : Mexico's Democratization in Comparative Perspective, (Cambridge, UK: Cambridge University Press, 2009): 6.

${ }^{69}$ Greene, Why Dominant Parties Lose, 5.

${ }^{70}$ Ibid., 6.
} 
their control over the politically dominated public sector needed to maintain the electoral authoritarian coercive apparatus, and therefore the PRI lost in the 2000 presidential elections. ${ }^{71}$

In a similar line of argument, Arriola examines African multiethnic societies, arguing that the electoral authoritarian incumbent can often hold on to their position through utilizing public resources to buycross-ethnic endorsements. ${ }^{72}$ The opposition, by contrast, needs to rely on the private sector's funds, but unlike the incumbent, they cannot compensate their potential patronage partners upfront, which makes coalition formation less likely. ${ }^{73}$ However, when incumbents lose their control over the business sector of the economy, no longer being able to afford the coercive apparatus, the opposition will then be able to sidestep the state's gatekeeping role in finance and challenge the incumbent. ${ }^{74}$ This occurred, for instance, in Kenya in 2002, when the opposition National Rainbow Coalition defeated the incumbent party KANU's candidate. ${ }^{75}$

Elite-led collapse, therefore, can take the form either of a coup, or of successful opposition mobilization. In both cases, the electoral authoritarian's decline in debt servicing ability will prevent them from utilizing pork and repression to maintain control over the state apparatus, as seen either from the need to implement severe austerity policies or the need to increase rent distribution to elites, ultimately leading to an elite-initiated collapse.

\section{Popular Mobilization-induced Collapse}

In response to austerity policies, it is not only the elites that can express discontent with, and potentially overthrow, the electoral authoritarian incumbent. Instead, the general population can also mobilize and forcefully remove the electoral authoritarian incumbent. Of course, opposition mobilization in elections, as discussed above, and popular mobilization are linked to an extent, but this section focuses on cases like the Arab Spring, in which popular mobilization and protests directly brought down electoral authoritarians.

\footnotetext{
${ }^{71}$ Ibid., 8.

${ }^{72}$ Arriola, Leonardo R, Multi-Ethnic Coalitions in Africa: Business Financing of Opposition Election Campaigns, (Cambridge, UK: Cambridge University Press, 2012): 19.

${ }^{73}$ Arriola, Multi-Ethnic Coalitions in Africa, 20.

${ }^{74}$ Ibid.

${ }^{75}$ Ibid., 43-44.
} 
Some protest is usually allowed, according to Lorentzen, for strategic reasons, even within electoral authoritarian regimes, as they allow the incumbent to gauge the extent of discontent and implement tactical repression. ${ }^{76}$ Still, widespread and popular protest can destabilize authoritarian regimes: with protests sweeping across North Africa and the Middle East, electoral authoritarian regimes were overthrown in Egypt and Tunisia in 2011. ${ }^{77}$ This process had strong economic links, with Arab Barometer finding that $63 \%$ of Tunisian respondents claimed a weak economy was the primary rationale behind the revolution. ${ }^{78}$ However, Tunisian economic performance was not in fact weak before the revolution; instead, the issue was that ordinary Tunisians were not beneficiaries of this growth due a lack of distribution. ${ }^{79}$ Albertus also highlights the role of distribution in land reform, arguing that some Latin American authoritarians implemented redistributive land reform to undercut the threat of instability from below, thereby acknowledging the potential threat that popular mobilization along economic lines can pose. ${ }^{80}$ Still, Geddes, Wright and Frantz find that popular uprisings account for only a minority (in their dataset, $17 \%{ }^{81}$ ) of the instances of authoritarian regime failures. Nonetheless, a decline in external debt servicing is hypothesized to lead to austerity towards the general population, which can lead to discontent, protest, and electoral authoritarian collapse.

In summary, when government expenditure changes in response to a decline in sovereign debt servicing ability, the decline in expenditure both towards the elite and the general population will mean both groups, but especially the former, will be incentivized to challenge the incumbent, leading to electoral authoritarian collapse.

\footnotetext{
76 Peter L. Lorentzen, "Regularizing Rioting: Permitting Public Protest in an Authoritarian Regime," Quarterly Journal of Political Science, 8.2 ( 2013): 128-129, http://dx.doi. org/10.1561/100.00012051.

${ }_{77}$ Mark L. Haas and David W. Lesch. The Arab Spring : Change and Resistance in the Middle East, (Boulder, Co: Westview Press, 2013): 3.

${ }^{78}$ Ghanem, Hafez. The Arab Spring Five Years Later, (Washington D.C.: Brookings Institution Press, 2016): vol. 1, 46.

${ }^{79}$ Ghanem, The Arab Spring Five Years Later, 46.

${ }^{80}$ Michael Albertus, Autocracy and Redistribution: the Politics of Land Reform, (New York, NY: Cambridge University Press 2015): 18.

${ }^{81}$ Geddes, Wright and Frantz, How Dictatorships Work, 179.
} 


\section{DATA}

The theory outlined above is tested in three steps, with each corresponding to one of the steps on Figure 1. The data used includes all 193 sovereign countries recognized by the United Nations as of early 2020, and it covers every country in every year between 1960 and 2010; this is referred to as country-years. The total number of observations in the complete dataset is 11580 , and the number of electoral authoritarian country-years is 7672 . First, the model will be presented. Next, the three mechanisms indicated on Figure 1 will be discussed in turn. Finally, the heterogeneous effects of the model will be discussed.

\section{THe ModeL}

The dependent variable is 'regime failure.' This binary variable from Geddes, Wright and Frantz's 2010 dataset takes on the value 1 if the authoritarian regime collapses in a given country-year, and 0 if it does not.

Figure 2: Number of Electoral Authoritarian Collapses 1960-2010

\section{NUMBER OF ELECTORAL AUTHORITARIAN COLLAPSES PER YEAR, 1960-2010}

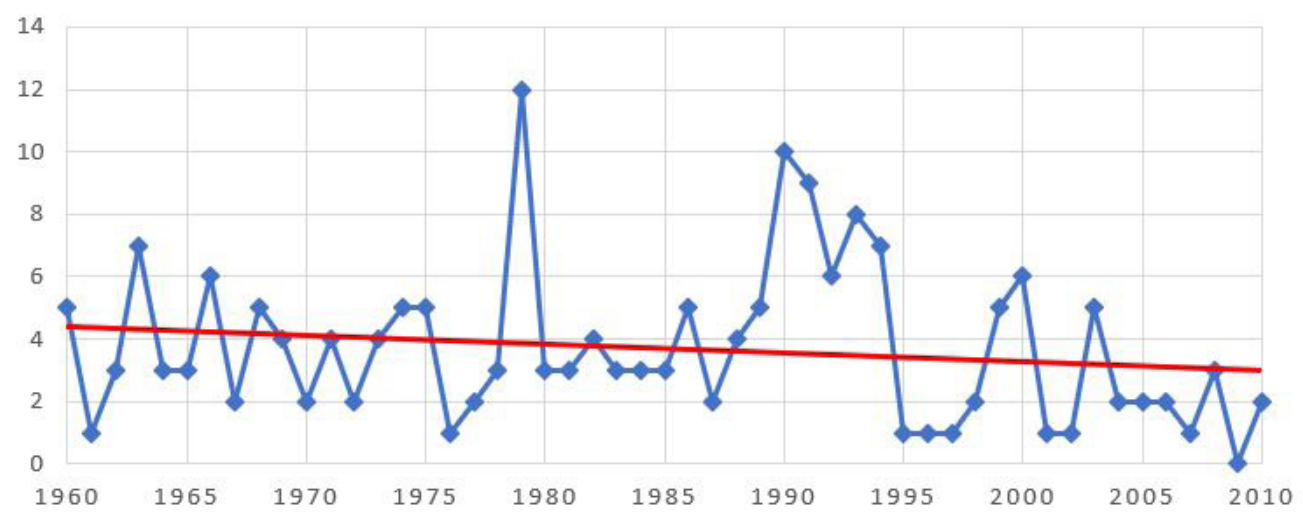

Figure 2 shows how the total annual number of collapses of electoral authoritarian regimes has evolved over time. The graph reveals two interesting points. First, the overall number of electoral authoritarian collapses is in decline, 
although not at a significant rate. This is illustrated by the red linear trendline. This change could either be the result of the number of electoral authoritarian regimes declining, or because electoral authoritarian regimes have become more resilient to collapse over time. The data appears to provide evidence for the former: the number of electoral authoritarian country-years in the first half of the sample, $1960-1985$, is 2098, while in the second half, from 1985-2010, it is 1720 . Still, investigating this question fully would require further study.

The second point to note about the graph is the two noticeable peaks of the data; firstly in 1979, which includes twelve cases of electoral authoritarian collapse, and secondly in the $1990-1994$ period, which includes an average of seven cases of collapse per year. The latter is largely explained by the end of the Cold War. This is due to the regime failures that followed the collapse of the Soviet Union, such as in Bulgaria and Poland. At the same time, the US, UK and France were becoming less likely to protect leaders they had supported only to uphold 'Western' regional hegemony over the Soviets. For instance, the 1990 Chadian coup was, in large part, able to succeed because the French stopped supporting the former incumbent, Hissène Habré, which allowed Idriss Déby to take power (and to remain in power as of early 2020). While French Foreign Minister Roland Dumas had the following to say about the Chadian coup, his statement encapsulates the broader geopolitical dynamics of the early 1990s: '[t] he times have passed when France would pick governments or would change governments and would maintain others when it so wished'. ${ }^{82}$ Including the observations of collapses in the immediate post-Cold War period may actually deflate the observed relationship, as the cause of their collapse is known to not be the result of debt servicing requirements. Enormous and unprecedented geopolitical changes such as the end of the Cold War notwithstanding, the 1979 spike in electoral authoritarian collapses is of particular interest. In that year, twelve electoral authoritarian regimes collapsed, primarily in Latin America and Africa. This can be explained, in large part, by the 1979 oil crisis. Unsurprisingly, GDP growth rates and government expenditures declined substantially in all but every instance of collapse in 1979 . This reinforces the theoretical framework that sharp economic shocks lead to changes in electoral authoritarian government expenditure, which in turn leads to regime collapse. The specific mechanics through which the dependent variable,

\footnotetext{
${ }^{82}$ Alan Riding, "Rebels in Control of Chad's Capital." The New York Times, The New York Times, December 3, 1990, www.nytimes.com/1990/12/03/world/rebels-in-control-of-chad-s-capital. html
} 
electoral authoritarian regime collapse, is affected by the independent variables will be investigated in this section.

The independent variables, taken from World Bank datasets, are as follows. Two types of shocks may occur that are of interest for the model: a change in the US interest rate, or a change in the commodity index. First, the US interest rate is taken into account through X1, a measure of the percentage change in the interest rate from one year to the next, as set by the Federal Reserve. A change in the interest rate affects debt servicing ability insofar as a country's debt is denominated in USD. Therefore, a second variable X2 denotes the percentage of USD-denominated public and publicly guaranteed (PPG) government debt. The second type of shock, a change in the commodity index, is captured by X3, which denotes the percentage change in the total amount of exports, seasonally adjusted, in current USD. This affects debt servicing ability to the extent that commodity rents contribute to GDP, and this percentage is represented by X4. These two shocks affect the size of the change in government expenditure as a percentage of GDP, which is captured by X5. Correlating with the economic downturn as a result of these shocks, percentage GDP growth is included as X6. The literature also uses control variables for past coups, measured by the binary indicator X7, which takes the value 1 if there was a coup (successful or not) in a given country-year and 0 otherwise; a binary indicator X8 which captures the occurrence of intrastate or interstate war in a given country-year; and an indicator X9 for the size of the country in $\mathrm{km} 2 .^{83}$ The effects of the independent variables are not lagged, because declines in external debt servicing are often short-term, acute crises, often occurring within the same year. The results are presented in Table 1.

Equation 1: The Model

$$
Y=X_{1} \beta_{1}+X_{2} \beta_{2}+X_{3} \beta_{3}+X_{4} \beta_{4}+X_{5} \beta_{5}+X_{6} \beta_{6}+X_{7} \beta_{7}+X_{8} \beta_{8}+X_{9} \beta_{9}+u
$$

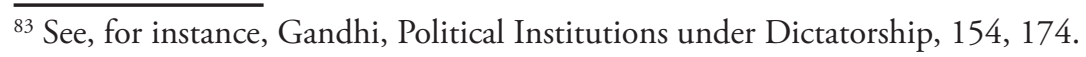


External Debt Servicing and Electoral Authoriatarian Regimes 25

\section{Main Results}

Table 1: The Model, Main Results

The standard errors are in brackets. Significance levels: ${ }^{*}-\mathrm{p}<10 \%$; ${ }^{* *}-\mathrm{p}<5 \%$; ${ }^{* *}-\mathrm{p}<1 \%$.

\begin{tabular}{|c|c|c|c|c|c|}
\hline & Model 1 & Model 2 & Model 3 & $\begin{array}{c}\text { Model } \\
4\end{array}$ & $\begin{array}{c}\text { Model } \\
5\end{array}$ \\
\hline \multirow{2}{*}{$\mathrm{X}_{1}$ : Interest rate change } & -0.016 & & 0.003 & 0.007 & 0.027 \\
\hline & $(0.584)$ & & $(0.070)$ & $(0.011)$ & $(0.073)$ \\
\hline \multirow{3}{*}{$\mathrm{X}_{2}:$ Debt $\% U S D$} & $0.006^{* *}$ & & $0.011^{* * *}$ & 0.011 & 0.014 \\
\hline & $(0.003)$ & & $(0.004)$ & $* * *$ & $* * *$ \\
\hline & & & & $(0.004)$ & $(0.005)$ \\
\hline \multirow{2}{*}{$\begin{array}{l}\mathrm{X}_{3}: \text { Commodity index } \\
\% \text { change }\end{array}$} & & 0.000 & 0.000 & 0.000 & 0.000 \\
\hline & & $(0.000)$ & $(0.000)$ & $(0.000)$ & $(0.000)$ \\
\hline \multirow[t]{2}{*}{$\begin{array}{l}\mathrm{X}_{4} \text { : Commodity rents } \\
\% \mathrm{GDP}\end{array}$} & & $\begin{array}{c}-0.028 \\
* * *\end{array}$ & $\begin{array}{c}-0.027^{* *} \\
(0.011)\end{array}$ & $\begin{array}{c}-0.026 \\
* *\end{array}$ & $\begin{array}{c}-0.030 \\
* *\end{array}$ \\
\hline & & $(0.010)$ & & $(0.011)$ & $(0.012)$ \\
\hline $\begin{array}{l}\mathrm{X}_{5} \text { : Government expen- } \\
\text { diture change } \\
\% \text { GDP }\end{array}$ & & & & $\begin{array}{l}0.040 * \\
(0.024)\end{array}$ & $\begin{array}{r}0.036 \\
(0.028)\end{array}$ \\
\hline $\mathrm{X}_{6}:$ GDP growth & & & & & $\begin{array}{l}-0.089 \\
* * * \\
(0.016)\end{array}$ \\
\hline $\mathrm{X}_{7}$ : Past coups & & & & & $\begin{array}{c}2.306 \\
* * * \\
(0.246) \\
\end{array}$ \\
\hline $\mathrm{X}_{8}:$ Land & & & & & $\begin{array}{l}0.000 \\
(0.000)\end{array}$ \\
\hline
\end{tabular}




\begin{tabular}{|c|c|c|c|c|c|}
\hline $\begin{array}{l}\mathrm{X}_{9} \text { : Intrastate / interstate } \\
\text { war }\end{array}$ & & & & & $\begin{array}{r}0.290 \\
(0.276) \\
\end{array}$ \\
\hline Number of observations & 3788 & 2192 & 2192 & 2192 & 2192 \\
\hline Intercept & $\begin{array}{c}-2.987 \\
* * * \\
(0.103)\end{array}$ & $\begin{array}{c}2.727 \\
* * * \\
(0.132)\end{array}$ & $\begin{array}{c}-3.161 \\
* * * \\
(0.214)\end{array}$ & $\begin{array}{c}-3.186 \\
* * * \\
(0.215)\end{array}$ & $\begin{array}{c}-3.353 \\
* * * \\
(0.256)\end{array}$ \\
\hline
\end{tabular}

Debt shocks can affect electoral authoritarian survival through two channels; the US interest rate and the commodity index. First, the coefficient on the percentage change in Federal Reserve interest rates is not statistically significant in and of itself, but intuitively it makes sense that a small change in the interest rate should not cause regime failures worldwide; instead, the US interest rate matters insofar as it influences the percentage of USD in a country's PPG debt profile. The percentage of USD in a country's PPG debt profile, however, is statistically significant at the $1 \%$ level. Model 5 in Table 1 shows that a $1 \%$ rise in the independent variable increases the likelihood of electoral authoritarian collapse by $1.4 \%$, which is a significant increase. For instance, prior to electoral authoritarian collapse in Ghana in 2000, the percentage of USD-denominated debt rose by $3.5 \%$ to $64.0 \%$. In addition to a decline in debt servicing ability through the US interest rate and the USD denomination of debt, the other mechanism through which a shock can affect electoral authoritarian stability is commodity rents. The coefficient on commodity index change is not statistically significant, and similarly to the US interest rate, intuitively it makes sense that commodity shocks only lead to electoral authoritarian collapse insofar as they worsen debt servicing ability. Debt servicing ability will worsen, however, through the change in commodity rents as a percentage of GDP. The coefficient on this variable is statistically significant for all of Models 2-5; in Model 5, which includes all other variables, a $1 \%$ decline in the variable makes electoral authoritarian collapse $3.0 \%$ more likely. This is connected to the literature on the resource curse, which argues that an abundance of natural resources will lead to an excessive reliance on commodities and export earnings for government revenues. ${ }^{84}$ This excessive dependence is exacerbated by the high volatility in

${ }^{84}$ Rabah Arezki, Amadou N R Sy, and Thorvaldur Gylfason, Beyond the Curse: Policies to 
commodity price fluctuations, and the subsequent financial and macroeconomic volatility. ${ }^{85}$ The vulnerability that this entails for electoral authoritarian countries in particular is demonstrated by the findings of Table 1 .

It is challenging to accurately conceptualize the change in government expenditure variable, because, for example, austerity towards the general population can include anything from a decline in staff members at municipal government offices to a change in one of the tiers of a progressive tax system. Capturing austerity towards the elites is perhaps even more challenging, because much of the electoral authoritarian leader's spending directed at their elites takes on intangible forms, such as those noted in Arriola, including, selective privatization deals or a nepotistic deployment of public services. ${ }^{86}$ Therefore, general government expenditure is used as a proxy; in Model 4 it is statistically significant at the $10 \%$ level, with a $1 \%$ increase in government expenditure as a percentage of GDP making the likelihood of electoral authoritarian collapse rise by $4.0 \%$. For example, prior to Sierra Leone's military coup in 1992, expenditure rose by $2.2 \%$. This is explained by how governments will attempt to raise expenditure temporarily, especially towards the elites, during a crisis to ensure their continued support. ${ }^{87}$ Gandhi and Przeworski discuss the two 'carrots' that the electoral authoritarian leader can offer: policy concessions and rent distribution. The latter shows that government expenditure rates and rents are crucial to the leader's attempt in maintaining support. ${ }^{88}$ Therefore, in Model 4 governments will temporarily raise rent distribution towards elites in response to a debt shock, which will send a signal of incumbent instability to the elites, who will be more likely to oust the electoral authoritarian leader. However, it is important to note that in Model 5, the coefficient on government expenditure changes is not statistically significant, and the heterogeneous effects involved in this will be investigated further.

Of the used control variables, GDP growth is statistically significant, meaning that a decline in GDP growth increases the likelihood of regime failure. Intuitively this makes sense: as posited by the argument, an economic shock and the subsequent decline in debt servicing ability is likely to lead to economic downturn,

Harness the Power of Natural Resources, (Washington D.C.: International Monetary Fund, 2011): 1 .

${ }^{85}$ Arezki, Sy, and Gylfason, Beyond the Resource Curse, 1.

${ }^{86}$ Arriola, Multi-Ethnic Coalitions in Africa, 19.

${ }^{87}$ Gandhi and Przeworski, Cooperation, Cooptation, and Rebellion, 1.

${ }^{88}$ Ibid. 
which this term captures. The binary indicator 'past coups' is also statistically significant: if past coups have occurred, whether successful or not, this will contribute to a track record of what McGowan calls 'elite political instability. ${ }^{\text {'9 }}$ However, as Svolik argues, elites generally prefer to avoid coups because they can be potentially costly and entail elite coordination problems. ${ }^{90}$ Therefore, there needs to be a catalyst for the culture of elite political instability to lead to a coup or other forms of elite mobilization against the incumbent; this catalyst can be an economic shock, such as a decline in debt servicing. Finally, while some of the literature posits that land size and intrastate or interstate war might have an effect on regime failure, neither of these coefficients are statistically significant.

In the next section, the three individual causal links (as shown on Figure 1) that underpin the model are explored.

\section{INVESTIGATING THE MeCHANISM}

\section{Step 1: Debt and Debt Servicing}

This step investigates the relationship between a rise in the US interest rate, a rise in the commodity index, and debt servicing ability. Debt servicing ability is measured by two indicators: first, the percentage of USD-denominated public and publicly guaranteed (PPG) government debt, and second, commodity rents as a percentage of GDP.

To understand the dynamics that work through the interest rate, the change in the percentage of debt denominated in USD is treated as the dependent variable and the interest rate as the independent variable. The independent variable is the change in the interest rate and not the interest rate itself because the percentage of USD in a country's PPG debt profile is determined by absolute, rather than relative, levels of the Federal Reserve rate. The results of the Ordinary Least Squares (OLS) regression are presented in Table 2.

\footnotetext{
${ }^{89}$ McGowan, “African Military Coups d'État," 339.

${ }^{90}$ Svolik, Power-Sharing and Leadership Dynamics, 481.
} 
Table 2: Step 1, Interest Rate, Results (Number of Observations: 2264)

The standard errors are in brackets. Significance levels: ${ }^{*}-\mathrm{p}<10 \%{ }^{* *}-\mathrm{p}<5 \%$; ${ }^{* *}-\mathrm{p}<1 \%$.

\begin{tabular}{|l|c|}
\hline & Estimate \\
\hline (Intercept) & $0.523^{* * *}$ \\
& $(0.138)$ \\
\hline Interest rate & $0.266^{* * *}$ \\
& $(0.100)$ \\
\hline $\mathrm{R}^{2}$ (adjusted) & 0.003 \\
\hline
\end{tabular}

The coefficient on the interest rate is statistically significant, indicating that a rise in the US interest rate will lead to a rise in the percentage of USD in a country's PPG debt profile. Specifically, a 1\% increase in the US interest rate leads to a $26.6 \%$ increase in the percentage of USD-denominated debt, which indicates that the latter variable will be strongly dependent on US interest rate fluctuations, and that debt servicing ability can vary considerably with changes in the Federal Reserve rate.

Next, to consider the dynamics that work through the commodity index, the change in the percentage of GDP composed of commodity rents is treated as the dependent variable, while the change in the commodity index is the independent variable. The reason both the dependent and the independent variable look at the change in their respective variables instead of overall values is so that the commodity index, which is in millions of current USD, does not become skewed depending on the size of the economy. The OLS regression's results are presented in Table 3.

Table 3: Step 1, Commodity Index, Results (Number of Observations: 2110)

The standard errors are in brackets. Significance levels: ${ }^{*}-\mathrm{p}<10 \%{ }^{* *}-\mathrm{p}<5 \%$; ${ }^{* *}-\mathrm{p}<1 \%$.

\begin{tabular}{|l|c|}
\hline & Estimate \\
\hline \multirow{2}{*}{ (Intercept) } & -0.009 \\
& $(0.107)$ \\
\hline
\end{tabular}




\begin{tabular}{|l|c|}
\hline Commodity index change & $\begin{array}{c}0.003^{* * *} \\
(0.000)\end{array}$ \\
\hline $\mathrm{R}^{2}$ (adjusted) & 0.008 \\
\hline
\end{tabular}

The coefficient on the commodity index change is statistically significant, indicating that if a country exports more in one period than another, the share of the country's GDP represented by commodity rents will rise. This underscores the dangers of a primary commodity export-driven economy. If a country becomes more exposed to the fluctuations of international markets, this will introduce greater uncertainty and instability to the economy, which is particularly debilitating for electoral authoritarians and their elite-coopting patronage networks.

A combination of these two channels, the interest rate and the commodity index, show that if an external shock hits the economy, the country's debt servicing ability will decline. Step 2 investigates the response of the electoral authoritarian leader to this predicament.

\section{Step 2: Debt Servicing and Government Expenditure}

The second step from Figure 1 investigates the relationship between debt servicing ability and changes in government expenditure. Debt servicing ability is operationalized as described above. Government expenditure is represented by a variable that indicates what percentage of GDP belongs to government expenditure. Bearing in mind the challenges of capturing the true extent of expenditure changes towards the elite in particular, the results of regressing the change in the percentage of USD-denominated debt and the change in the percentage of GDP that commodity rents comprise on the change in government expenditure as a percentage of GDP are shown in Table 4. The regression is an OLS regression. 
Table 4: Step 2, Results (Number of Observations: 2063)

The standard errors are in brackets. Significance levels: ${ }^{*}-\mathrm{p}<10 \%$; $^{* *}-\mathrm{p}<5 \%$; ${ }^{* *}-\mathrm{p}<1 \%$.

\begin{tabular}{|l|c|}
\hline & Estimate \\
\hline (Intercept) & $0.1418^{* *}$ \\
& $(0.711)$ \\
\hline Change debt \%USD & $-0.291^{* *}$ \\
& $(0.115)$ \\
\hline Change commodity rents \%GDP & $-0.069^{* * *}$ \\
\hline $\mathrm{R}^{2}$ (adjusted) & $(0.158)$ \\
\hline
\end{tabular}

Table 4 shows that the coefficients on the change in the percentage of USD in a country's PPG debt, and the change in the percentage of commodity rents as a part of GDP, are both statistically significant. The negative coefficient for both variables indicates that if one of the independent variables rises, then the government expenditure level will fall. Specifically, a 1\% rise in the percentage of debt denominated in USD will lead to a $29.1 \%$ decline in government expenditure, while a similar increase in commodity rents as a percentage of GDP will lower by $6.9 \%$. This confirms that government spending, and the patronage networks it is tied to, are strongly affected by a decline in debt servicing ability either as a result of a change in the currency composition of debt or a change in commodity rents as a percentage of GDP.

\section{Step 3: Government Expenditure and Electoral Authoritarian Collapse}

The final step investigates the relationship between government expenditure and the collapse of electoral authoritarian regimes. The dependent variable is the binary variable 'regime failure' which denotes whether authoritarian regimes do indeed collapse or not. This is regressed against the independent variable, the change in government expenditure as a percentage of GDP. The results of the logit regression are presented in Table 5. 
Table 5: Step 3, Regime Failure with No Restrictions, Results (Number of Observations 3854)

The standard errors are in brackets. Significance levels: ${ }^{*}-\mathrm{p}<10 \%$; $^{* *}-\mathrm{p}<5 \%$; $^{* *}-\mathrm{p}<1 \%$.

\begin{tabular}{|l|c|}
\hline & Estimate \\
\hline (Intercept) & $-3.001^{* * *}$ \\
& $(0.076)$ \\
\hline $\begin{array}{l}\text { Government expenditure change } \\
\text { \%GDP }\end{array}$ & 0.029 \\
\hline
\end{tabular}

The coefficient on the independent variable is not statistically significant, but it is close to the $10 \%$ significance threshold with a p-value of 0.145 . The estimate is 0.029 , and its positive value means that a rise in government expenditure will lead to a higher likelihood of electoral authoritarian collapse. As outlined in the theory section, rent distribution is a key method of maintaining electoral authoritarian control over the leader's elite-dominated patronage networks. When a shock leads to a decline in external debt servicing ability,electoral authoritarian leaders will have an incentive to uphold the integrity of those networks, and they might increase government expenditure to do so. Still, the presence of institutions, such as legislatures, will make it more difficult for the leader to conceal from elites a declining ability to service external debt servicing ability and to address economic difficulties more generally. This, in turn, highlights the vulnerability of the electoral authoritarian leader. The elites will then be incentivized to act on this information, and move to oust the leader. Still, the coefficient is not statistically significant, and the reasons for that divergence are investigated in the following section.

\section{Heterogeneous EfFects}

The theory section posited that electoral authoritarian collapse could originate from two stakeholders: the elite and the general population. Geddes' dataset contains information that might allow these stakeholders' impact to be disaggregated. Namely, it contains a categorical variable denoting regime failure type, and a categorical variable denoting the amount of violence during a regime 
failure. While violence can occur even in cases when an uprising is successfully prevented, quantifying such effects is challenging and outside the scope of this article. ${ }^{91}$

The three types of regime failure that happened more than thirty times are military coups (fifty-nine times), elections (fifty-four times), and uprisings (thirtyfour times). The reason thirty was chosen as a threshold is because the fourth-most likely cause of collapse, civil war, occurs only fourteen times, which is less than half of the third-most likely cause. Other causes include foreign intervention and state failure. Disaggregating these three main types of regime failure yields interesting insights into the reasons for different types of collapse. The key conceptual framework is presented in Figure 2.

Figure 2 - Model Extension Framework

\begin{tabular}{|l|c|c|}
\hline & None or little violence & Significant violence \\
\hline Elites predominant & Military coup & \\
\hline Elites + population & \multicolumn{2}{|c|}{ Elections } \\
\hline Population predominant & & Uprising \\
\hline
\end{tabular}

\section{Military Coup}

Military coups are widely regarded as an elite-led affair which generally involve few casualties, as indicated by their placement in Figure 2. McGowan highlights that coups are "a change in power from the top," indicating the centrality of elite interactions in causing military coups. ${ }^{92}$ Similarly, Gutteridge places emphasis on elite interpersonal relations as the primary cause of coups in general, with the military elites being a part of the broader network of elites. ${ }^{93}$ The number of casualties is generally small because electoral authoritarian regimes by nature concentrate power in the hands of the electoral authoritarian leader and a narrow cohort of allies, which makes targeted military intervention much more likely to succeed in a way that does not disrupt society more broadly. ${ }^{94}$ This relationship is

\footnotetext{
${ }^{91}$ Janet I. Lewis, "How Does Ethnic Rebellion Start?" Comparative Political Studies, 50.10 (2017): 1420, https://doi.org/10.1177/0010414016672235

${ }_{92}$ McGowan, "African Military Coups d'État," 342

${ }^{33}$ William Gutteridge, "The Military in African Politics - Success or Failure?" Journal of Contemporary African Studies, 1.2 (1982): 243.

${ }^{94}$ Ruth First, The Barrel of a Gun: Political Power in Africa and the Coup d'État, (London: Allen
} 
demonstrated below by the OLS regression in Table 6 . The independent variable is a binary indicator that takes the value 1 if a regime failure had no casualties, and 0 otherwise. The dependent variable is a binary variable that takes the value 1 if an instance of electoral authoritarian collapse was caused by a military coup, and 0 otherwise.

Table 6: Model Extension, Military Coups and Violence (Number of Observations: 3902)

The standard errors are in brackets. Significance levels: ${ }^{*}-\mathrm{p}<10 \%$; $^{* *}-\mathrm{p}<5 \%$; ${ }^{* * *}-\mathrm{p}<1 \%$.

\begin{tabular}{|l|c|}
\hline & Estimate \\
\hline (Intercept) & $0.007^{* * *}$ \\
& $(0.002)$ \\
\hline Regime failure, no casualties & $0.343^{* * *}$ \\
& $(0.011)$ \\
\hline
\end{tabular}

The results of logit regressing the model's key independent variables on the dependent binary variable of 'military coups' are presented in Table 7.

Table 7: Model Extension, Military Coups (Number of Observations, 1638)

The standard errors are in brackets. Significance levels: ${ }^{*}-\mathrm{p}<10 \%$; $^{* *}-\mathrm{p}<5 \%$; ${ }^{* * *}-\mathrm{p}<1 \%$.

\begin{tabular}{|l|c|}
\hline & Estimate \\
\hline (Intercept) & $-4.287^{* * *}$ \\
& $(0.218)$ \\
\hline \multirow{2}{*}{ Interest rate change } & -0.095 \\
& $(0.143)$ \\
\hline \multirow{2}{*}{ Change debt \%USD } & 0.003 \\
& $(0.035)$ \\
\hline
\end{tabular}

Lane, 1970): 4-5. 
External Debt Servicing and Electoral Authoriatarian Regimes 35

\begin{tabular}{|l|c|}
\hline Commodity index change & 0.000 \\
& $(0.000)$ \\
\hline Change commodity rents \%GDP & 0.034 \\
& $(0.046)$ \\
\hline $\begin{array}{l}\text { Government expenditure change } \\
\text { \%GDP }\end{array}$ & $0.085^{* * *}$ \\
\hline
\end{tabular}

As Table 7 shows, the coefficient on the change in government expenditure as a percentage of GDP is statistically significant. However, the coefficient is positive, which means that a $1 \%$ rise in government expenditure as a percentage of GDP makes electoral authoritarian collapse more likely by $8.5 \%$. For example, government expenditure rose by $5.4 \%$ prior to Liberia's military coup in 1980 . This suggests the validity of the previously posited hypothesis that, when faced with a shock and a subsequent decline in external debt servicing ability, electoral authoritarian leaders will try to maintain their patronage-fueled networks with the elite. This will entail a rise in government expenditure, as Table 7 shows. Upon seeing this attempt at buying their compliance amidst an economic crisis, elites will be incentivized to oust the leader. Indeed, it is no mistake that this effect is statistically significant for military coups specifically, which Figure 2 indicates are elite-dominated. It is also no surprise that transfers to the elite are crucial in maintaining electoral authoritarian stability. For instance, Tyburski argues that subsidies from state and federal governments have been historically linked to elite transfers and corruption in Mexico. ${ }^{95}$ When faced with a crisis, electoral authoritarian leaders will therefore double down on these networks. This, however, will send a message of incumbent vulnerability to the elite. When combined with the free flow of information about the state of the economy in institutions like the legislature, the elite will likely move to oust the leader through a military coup.

\section{Elections}

In the Geddes, Wright and Frantz dataset, elections cause authoritarian regime failure in fifty-four cases, either because the incumbent loses an election, or

\footnotetext{
${ }^{95}$ Michael D. Tyburski, “The Resource Curse Reversed? Remittances and Corruption in Mexico," International Studies Quarterly, 56.2 (2012): 343.
} 
because they do not stand for re-election. An electoral defeat of the incumbent relies on support from both the general population and the elites, and it can vary in the amount of violence it entails, as Figure 2 shows. First, elections provide an outlet for elites and the general population to unite. On the incumbent elites' part, every election necessitates re-confirming the incumbent candidate for head of state as the party's representative. When the incumbent is not seeking reelection, this repeated uncertainty can divide weakly institutionalized parties where personalized politics are significant due to the nature of electoral authoritarianism. ${ }^{96}$ For the opposition elites', every election provides an opportunity to form coalitions that can lead to what Howard and Roessler call 'liberalizing electoral outcomes.' ${ }^{97}$ To the extent that opposition elites can come together and present a united and competent front against the incumbent, their coalition can take votes away from the incumbent by abandoning the "divide and rule" strategy. ${ }^{98}$ Of course, the labels 'incumbent elites' and 'opposition elites' are often not fixed, and people can have incentives to move between the groups in every election. The general population's involvement in elections is crucial as well; after all, it is they who actually cast votes for the incumbent or the opposition. This interaction can be shown through the example of Kenya's electoral authoritarian turnover of 2002, where elite interactions led the former incumbent Kenyatta not to seek reelection and KANU, the incumbent party, to support Moi instead. The opposition, after decades of fragmentation, united to form the National Rainbow Coalition. Civil society and grassroots movements mobilized in support of the coalition, leading to its electoral victory. ${ }^{99}$

The degree of violence involved during a turnover by election varies as well. While Kenya's 2002 election did not involve any casualties, the Sri Lankan election of 1994, which ended 17 years of authoritarian rule by the United National Party, was marred with assassinations and widespread violence. ${ }^{100}$ The Geddes, Wright and Frantz dataset places the casualty rate between 26 and 1000 . This variation explains why Figure 2 shows 'elections' encompassing both high and low rates of violence.

\footnotetext{
${ }^{96}$ Cheeseman, "African Elections, 142.

${ }^{97}$ Howard and Roessler, "Liberalizing Electoral Outcomes," 371.

${ }^{98}$ Howard and Roessler, "Liberalizing Electoral Outcomes," 371.

${ }^{99}$ Howard and Roessler, "Liberalizing Electoral Outcomes," 377-380.

${ }^{100}$ Gamini Keerawalla and Rohan Samarajiva, "Sri Lanka in 1994: A Mandate for Peace," Asian Survey, 35.2 (1995): 153-159.
} 
The results of logit regressing the general model's key independent variables on the dependent binary variable of 'elections' are shown in Table 8.

Table 8: Model Extension, Elections (Number of Observations: 1638)

The standard errors are in brackets. Significance levels: ${ }^{*}-\mathrm{p}<10 \%$; $^{* *}-\mathrm{p}<5 \%$; ${ }^{* * *}-\mathrm{p}<1 \%$.

\begin{tabular}{|l|c|}
\hline & Estimate \\
\hline (Intercept) & -3.879 \\
& $(0.181)$ \\
\hline Interest rate change & 0.034 \\
& $(0.120)$ \\
\hline Change debt \%USD & $0.052^{*}$ \\
\hline Commodity index change & $(0.029)$ \\
\hline Change commodity rents \%GDP & 0.000 \\
\hline Government expenditure change & $(0.000)$ \\
\hline \%GDP & $0.067^{* *}$ \\
\hline
\end{tabular}

Table 8 shows that the coefficient on the change in the percentage of PPG debt denominated in USD and the change in the percentage of commodity rents as a percentage of GDP are statistically significant. The former indicates that the likelihood of regime failure rises as more of a country's debt profile becomes denominated in USD, given the change's effect on subsequent policy decisions. The rising debt burden will undercut the legitimacy of the electoral authoritarian leader both in the eyes of the elite and the general population, projecting an inability to tackle the effects of the economic shock. Table 8 therefore shows that a $1 \%$ rise in the percentage of PPG debt in USD will increase the likelihood of collapse through elections by $5.2 \%$. The second statistically significant predictor of collapse is the change in commodity rents as a percentage of GDP. A $1 \%$ rise in the variable 
makes electoral authoritarian collapse in the form of elections $6.7 \%$ more likely. This finding points to an additional causal channel through which economic shocks might affect electoral authoritarian collapse. If a country's exports decline relative to GDP, then not only will that incentivize collapse through the channels of government expenditure as discussed thus far, but it will also directly harm people working in the export sector. A rise in commodity rents as a percentage of GDP means that the economy is becoming increasingly dependent on exports, which exposes it to the fluctuations of the global economy. ${ }^{101}$ This volatility and uncertainty will adversely affect those working in the export sector and their perceptions of the government, which can mobilize anti-incumbent movement. Therefore, electoral authoritarian collapse by elections is best predicted by an increase in the percentage of USD-denominated debt and the rise of commodity rents as a percentage of GDP.

\section{Uprisings}

The final method of electoral authoritarian regime failure that accounts for a significant number of cases is uprisings (thirty-four instances). These represent cases in which the general population rises up against the electoral authoritarian incumbent, indicating that agency lies primarily not with the elites but with 'the people.' This type of regime failure usually entails violence, as demonstrated by most countries' experiences during the Arab Spring. ${ }^{102}$ This relationship is shown by the OLS regression in Table 9.

Table 9: Model Extension, Uprisings and Violence (Number of Observations: 3902)

The standard errors are in brackets. Significance levels: ${ }^{*}-\mathrm{p}<10 \%{ }^{* *}-\mathrm{p}<5 \%$; ${ }^{* *}-\mathrm{p}<1 \%$.

\begin{tabular}{|l|c|}
\hline & Estimate \\
\hline (Intercept) & 0.008 \\
& $(0.001)$ \\
\hline Regime failure, $>1000$ casualties & $0.072^{* * *}$ \\
& $(0.019)$ \\
\hline
\end{tabular}

${ }^{101}$ Campello and Zucco, Presidential Success and the World Economy, 590.

${ }^{102}$ Haas and Lesch, The Arab Spring, 3. 
The results of regressing the model's key independent variables on the dependent binary variable of uprisings are shown in Table 10. It is posited that not every decline in government expenditure will lead to an uprising against electoral authoritarians. Indeed, uprisings usually occur in times of severe crisis. This is because uprisings can occur if the economic shock and the ensuing austerity policies are severe enough that the coordination problem can be overcome by protestors. Therefore, unlike Tables 7 and 8 , there is a control for the size of the change in government expenditure. This control is -3.6 , which is double the average of negative changes in government expenditure.

Table 10: Model Extension, Uprisings (Number of Observations: 1074)

The standard errors are in brackets. Significance levels: ${ }^{*}-\mathrm{p}<10 \%{ }^{* *}-\mathrm{p}<5 \%$; ${ }^{* *}-\mathrm{p}<1 \%$.

\begin{tabular}{|l|c|}
\hline & Estimate \\
\hline (Intercept) & -4.417 \\
& $(1.627)$ \\
\hline Interest rate change & 0.209 \\
& $(0.586)$ \\
\hline Change debt \%USD & -0.007 \\
& $(0.124)$ \\
\hline Commodity index change & 0.000 \\
Change commodity rents \%GDP & $(0.001)$ \\
\hline Government expenditure change & -0.055 \\
\%GDP & $(0.157)$ \\
\hline
\end{tabular}

Table 10 shows that the coefficient on the change in government expenditure as a percentage of GDP is statistically significant. Unlike the coefficient on the variable in the regression in Table 7 , which repeats this regression but for military 
coups, the coefficient here is negative. This means that a $1 \%$ decline in government expenditure as a percentage of GDP leads to a $16.0 \%$ rise in the probability of electoral authoritarian collapse by uprisings. This confirms the main hypothesis posited for the mechanism through which government expenditure and electoral authoritarian regime stability are linked: if austerity policies are implemented, uprisings are more likely to oust the leader. Crucially, this mechanism only holds if the decline in government expenditure is sufficiently large. If it exceeds twice the average of negative changes in government expenditure, austerity policies towards the general population will indeed lead to uprisings. In summary, if social spending policies are drastically scaled back, the ensuing outrage can manifest in the form of an uprising, leading to the failure of the electoral authoritarian regime.

To conclude, the model as shown in Table 1 indicates that an increase in the percentage of debt denominated in USD, an increase in the percentage of GDP composed of commodity rents, and an increase in the percentage of GDP composed of government expenditure will all make electoral authoritarian collapse more likely. Heterogeneous effects can be observed: military coups, which are an elite-driven affair and feature little violence, are best predicted by an increase in the percentage of GDP composed of government expenditure. This is because, following a debt shock, the incumbent will try to temporarily increase the rents distributed to elites in an attempt to forestall action against themselves. Still, the elites will interpret this as a sign of instability and therefore will likely stage a military coup. Elections, by contrast, are best predicted by increases in the percentage of debt denominated in USD and in the percentage of GDP composed of commodity rents; instances of electoral authoritarian collapse by elections feature both elite mobilization and popular mobilization, and can involve varying amounts of violence. Finally, popular uprisings are best predicted by a decline in the government expenditure as a percentage of GDP, given that this change is above the $-3.6 \%$ threshold. This is significant because it is only substantial austerity policies that will lead to discontent capable of overcoming the general population's collective action problem. Given the nature of popular mobilization, these instances of electoral authoritarian collapse usually feature violence. In sum, exogenous shocks will worsen debt servicing ability, which will lead to a change in government expenditure, in turn leading to different forms of electoral authoritarian collapse. 


\section{Case Study}

The theoretical and empirical analysis will now be examined through case study. Two instances of electoral authoritarian regime failure in The Gambia will be analyzed. The first one occurred on July 22, 1994, when then-Lieutenant Yahya Jammeh launched a military coup against the former President Jawara. The second occurred in December 2016, when opposition presidential candidate Adama Barrow defeated Jammeh. These two regime failures - a nonviolent military coup, and a mostly nonviolent election - illustrate the theoretical framework discussed thus far in practice.

\section{JuLY 22, 1994}

The Gambia achieved independence from the UK in 1965, and elections with universal suffrage were put in place. The first presidential election was won by Dawda Kairaba Jawara of the People's Progressive Party (PPP), as were all subsequent elections for the next 24 years. ${ }^{103}$ Elections were always contested by multiple parties; Wiseman and Vidler have argued that The Gambia had 'regular free and (relatively) fair elections' during the 1965-1994 period. ${ }^{104}$ Similarly, Hughes characterized Jawara's regime as a "functioning democracy." 105 The OAU's Africa Charter on Human and People's Rights, which came into force in 1986, was drawn up in The Gambia. ${ }^{106}$ In the decades when much of Western Africa was experiencing frequent military coups, The Gambia was a relatively stable state. ${ }^{107}$

The Gambia's primary export during the pre-coup years was, and has remained, the groundnut. ${ }^{108}$ The country sought stabilization packages between 1978-85 from the IMF primarily due to a decline in global groundnut prices, with output falling by $40 \%$ in $1977-1978 .{ }^{109}$ The crisis highlighted how precarious The Gambias integration in the global economy was, with external debt servicing

\footnotetext{
$\overline{103}$ John A. Wiseman and Elizabeth Vidler. "The July 1994 Coup d'État in the Gambia: The End of an Era?" The Round Table, 84.333 (1995): 53.

${ }^{104}$ Wiseman and Vidler, "The July 1994 Coup d'État in the Gambia," 58-59.

105 Arnold Hughes, "Democratisation' under the Military in The Gambia: 1994-2000," Commonwealth \& Comparative Politics, 38.3 (2000): 36.

${ }^{106}$ Wiseman and Vidler, "The July 1994 Coup d'État in the Gambia," 54.

${ }^{107}$ McGowan, "African Military Coups d'État," 339.

${ }^{108}$ David Cooke and Arnold Hughes, "The Politics of Economic Recovery: The Gambia's Experience of Structural Adjustment, 1985-94," The Journal of Commonwealth \& Comparative Politics, 35.1 (1997): 94.

${ }^{109}$ Cooke and Hughes, "The Politics of Economic Recovery," 94.
} 
overtaking groundnut export revenues in 1984-1985. ${ }^{110}$ Still, the economy did improve in the next few years, due in part to a policy bundle of floating the currency, liberalizing the economy and privatizing state-owned companies. More importantly, the economy benefited from the global upswing in groundnut prices, with the commodity's world price rising by $35 \%$ between 1985 and $1989 .{ }^{111}$ This meant that as the 1990s began, the economy had recovered as outstanding debt levels were no longer spiraling, and commodity rents had largely returned to their pre-crisis levels. Government expenditure as a percentage of GDP, however, was low, and in 1994, it fell by 3.8\%. Public sector employment had also declined during the 1980 s. $^{112}$ This combination of cautious recovery and austerity had a particularly significant effect on the military.

Following independence, The Gambia's formal army was established in 1982. It was this army whose junior leadership would oust Jawara in 1994, and they did so for two primary reasons: resentment due to government expenditure, and resentment due to personal grievances. ${ }^{113}$

Firstly, the changes in government expenditure implemented in the country had negatively affected the military. Many Gambian junior officers resented the quality of their food, accommodation and pay in the years prior to the coup. ${ }^{114}$ Even more damningly, the payments of allowances for services in the ECOMOG peacekeeping force in Liberia were late, and this further fueled the military's discontent with Jawara's austerity policies. ${ }^{115}$ In line with the broader theoretical background, there is evidence that the government attempted to respond to these grievances immediately before the coup. They promoted some rank and file troops and gave larger allowances to certain parts of the military, but it was too little too late; a coup was in the making. ${ }^{116}$ This confirms Gandhi and Przeworski's observation that a temporary increase in rent distribution following a decline in debt servicing signals incumbent instability to the elites, which, as

\footnotetext{
110 Ibid, 95.

${ }^{111}$ Ibid, 96, 105.

${ }^{112}$ Arnold Hughes and David Perfect, A Political History of the Gambia, 1816-1994, (Rochester, NY: University of Rochester Press, 2006): 282.

${ }^{113}$ Hughes and Perfect, A Political History of the Gambia, 282.

${ }^{114}$ Ibid., 282.

115 Wiseman and Vidler, “The July 1994 Coup d'État in the Gambia," 59.

${ }^{116}$ Hughes and Perfect, A Political History of the Gambia, 283.
} 
Table 7 shows, means that a military coup is likely to oust the incumbent. ${ }^{117}$

The second reason for the July 1994 coup was resentment due to personal grievances. This point shows that there are individual, idiosyncratic factors at play in any given coup that a general model cannot fully capture. After a formal military was established, sixty-nine officers of the Nigerian Armed Forces Training Group were brought to The Gambia and promoted to senior positions. ${ }^{118}$ Hughes and Perfect state that "by 1993 Nigerians (...) held all (...) senior positions in the army." 119 Discontent among the Gambian junior officers and their grievances about low pay and poor quality food and accommodation were amplified by their remuneration in contrast to the better-compensated Nigerian senior officers. ${ }^{120}$ Indeed, the trigger for the coup was a similarly idiosyncratic factor: on July 21, 1994, Jammeh's soldier allies had gone to the airport to pick up Jawara as he returned to The Gambia. Before they could do so, the officers were unexpectedly searched by a Nigerian Colonel, an act considered humiliating and that led to fury among the junior officers. Jammeh would later go on to claim that he had planned the coup that night, from July 21-22, with his fellow discontented lieutenants. ${ }^{121}$ Of course, it is hard to quantify the extent to which resentment over Nigerian senior leadership, or over the July 21 incident, contributed to the coup. Still, these personal grievances amplified the pre-existing discontent about changing levels of government expenditure for the military. These changes in expenditure provided the systemic leverage, while personal grievances determined the precise timing of the coup.

On the morning of July 22, 1994, Jammeh and his allies took over the airport, the radio station and the State House. ${ }^{122}$ There was no bloodshed during their coup; Wiseman and Vidler claim that "the take-over on the whole met with little resistance," with Jawara escaping on a US landing ship. ${ }^{123}$ Jawara attempted to request American and Senegalese assistance in putting down the coup, but by the end of July 22, it became clear that this would not happen. ${ }^{124}$ The coup was

\footnotetext{
${ }_{117}$ Gandhi and Przeworski, "Cooperation, Cooptation, and Rebellion," 1.

${ }^{118}$ Hughes and Perfect, A Political History of the Gambia, 281.

119 Ibid.

${ }^{120}$ Ibid., 282.

${ }^{121}$ Ibid., 286.

122 Wiseman and Vidler, “The July 1994 Coup d'État in the Gambia,” 56.

${ }^{123}$ Ibid., 57.

${ }^{124}$ Ibid., 60.
} 
therefore over; it was a "bloodless" 125 affair, in which "[t] he Gambian people themselves were little more than onlookers of events in their country." 126 Therefore, in line with Figure 2 and Table 7, this elite-led military coup involved no violence, and was largely a result of a rise in government expenditure in an attempt to maintain elite co-optation following an economic shock, which the military correctly perceived as a signal of instability and responded to with a coup.

\section{Interlude}

In the years between 1994 and 2016, Yahya Jammeh served as the President of The Gambia. After taking power, he announced that elections would be held in 1996, but in the interim, political violence skyrocketed. Two days before the 1996 elections, the United Democratic Party (UDP), the main opposition party, had over 150 people injured, tortured or killed after one of their campaign rallies. ${ }^{127}$ The UDP's leader, Ousainou Darboe, sought refuge at the Senegalese High Commission in The Gambian capital of Banjul on the day of the election after receiving death threats from pro-government militants. ${ }^{128}$ Institutions were not free from political influence either. Jammeh modified the constitution to lower the minimum age for presidential candidates from forty to thirty (Jammeh was thirty-one years old at the time), ${ }^{129}$ and the formerly independent electoral commission, PIEC, was infiltrated and districts were gerrymandered. ${ }^{130}$ Unsurprisingly, Jammeh won a supermajority in the election - and in the elections that followed for the next two decades.

Jammeh's rule was, in some ways, typical of electoral authoritarians. He built schools, hospitals, roads, state-owned radio stations and The Gambia's first university. ${ }^{131} \mathrm{He}$ used these projects as opportunities to expand his network of state patronage, consolidating his hegemony by expanding the networks Jawara

\footnotetext{
${ }^{125}$ Hughes and Perfect, A Political History of the Gambia, 287.

126 Wiseman and Vidler, "The July 1994 Coup d'État in the Gambia," 61.

${ }^{127}$ Hughes, ",Democratisation' under the Military in The Gambia,” 38.

${ }^{128}$ Ibid.

${ }^{129}$ Ibid., 40.

${ }^{130}$ Ibid.

${ }^{131}$ Abdoulaye Saine, "Post-Coup Politics in the Gambia," Journal of Democracy, 13.4 (2002): 168.
} 
had established. ${ }^{132}$ However, even by electoral authoritarian standards, Jammeh's rule was unusually colorful. In 2014, he said that "[w]e will fight these vermins [sic] called homosexuals or gays the same way we are fighting malaria-causing mosquitoes, if not more aggressively." "133 While he banned female genital mutilation in 2015, after decades of claiming that the practice formed a part of Gambian culture, his track record as a champion for gender equality becomes questionable as he is currently facing charges for multiple counts of rape. During his tenure, the international community spoke out against his regime. In 2016, he responded that "Ban Ki-moon and Amnesty International can go to hell! Who are they to demand it? What is the problem? It is very common for people to die in detention or during interrogation. No one will tell me what to do in my country!"134

\section{December 1, 2016}

On December 1, 2016, something unexpected happened. Adama Barrow, the UDP presidential candidate, defeated Jammeh, winning $43.3 \%$ over the former president's $39.6 \% .{ }^{135}$ Turnout was over 70\%; Jammeh made a televised concession the following day. ${ }^{136}$ The reasons for this electoral authoritarian turnover are twofold. First, the Gambia's economic situation was such that turnover became possible, both from the elite's and the general population's perspective; second, a combination of strategic blunders from Jammeh and strategic successes by the opposition led to the electoral defeat.

The Gambia had been struggling economically at the beginning of 2016. An IMF Debt Sustainability report stated, on March 5, 2015, that The Gambia had a heavy and risky public debt burden. ${ }^{137}$ Still, it was the April 2016 closure of borders with neighboring Senegal due to a trade dispute, and the following

\footnotetext{
${ }^{132}$ Hughes, “,Democratisation' under the Military in The Gambia,” 48.

133 "Gambia's Jammeh Calls Gays ,Vermin', Says to Fight like Mosquitoes." Reuters, Thomson Reuters, February 18, 2014, www.reuters.com/article/us-gambia-homosexuality/gambias-jammehcalls-gays-vermin-says-to-fight-like-mosquitoes-idUSBREA1H1S820140218

134 “,Ban Ki-Moon and Amnesty International Can Go to Hell' Says Gambian President Jammeh.” Blasting News,May 29, 2016, us.blastingnews.com/world/2016/05/ban-ki-moon-and-amnestyinternational-can-go-to-hell-says-gambian-president-jammeh-00943399.html

${ }^{135}$ Kora and Darboe, "The Gambia's Electoral Earthquake," 147.

${ }^{136}$ Ibid., 147, 154.

${ }^{137}$ International Monetary Fund, “The Gambia: Debt Sustainability Analysis,” Approved by Roger Nord, Luis Cubeddo, and John Panzer, March 4, 2015, .https://www.imf.org/external/pubs/ft/dsa/ pdf/2015/dsacr15104.pdf
} 
decline in exports that truly started the crisis. This exogenous shock damaged The Gambia's economy through the channels of debt and commodity rents. Drammeh states that by late 2016, total public debt comprised $100 \%$ of GDP in nominal terms. ${ }^{138}$ Given that the percentage of USD in its PPG debt profile was $46 \%$ in 2016, increasing from the previous year by a significant $1.3 \%$, the fact that the US interest rate had risen by over $1 \%$ in the previous two years was particularly worrying. The other source of economic difficulties was rooted in the country's dependence on commodity exports, and exacerbated by a shock. The Gambia's small and open economy remained vulnerable to external fluctuations of exports. Moreover, with Senegal closing its borders to trade with The Gambia in early 2016, commodity rents plummeted. ${ }^{139}$ This led to a sharp fall in employment among those working in export-oriented industries, and with youth unemployment already high across the country, the crisis deepened even further. ${ }^{140}$ These factors led to a decline in debt servicing, meaning that the government ran an even deeper deficit, which limited its capacity to resolve these economic issues. ${ }^{141}$ In line with Table 8 , it is a combination of a rise in the percentage of USD-denominated debt, and a rise in the commodity rents as a percentage of GDP, that predicate electoral authoritarian collapse by elections, and The Gambia's economic crisis confirms this pattern.

While economic changes led to Jammeh's downfall, the fact that Barrow was able to unite an opposition coalition the way he did was rooted in the idiosyncrasies of Jammeh's strategic mistakes, and Barrow's and the opposition's strategic successes. Firstly, Jammeh made strategic blunders, having become too lax about his hegemony. Given his near-complete monopoly on the patronage network created for state resources, he might well have thought he had no reason to fear any opposition candidate at the 2016 election. ${ }^{142}$ However, Kora and Darboe highlight three key mistakes he made: first, when people protested an election law he had passed in April 2016, he uncharacteristically ordered a brutal crackdown on the protestors. The leader, Solo Sandeng, was killed, and many more

\footnotetext{
${ }^{138}$ Seedy Drammeh, Perspectives on New Gambia, (The Gambia: the Centre for Media and Development Research in Africa, 2018): 9.

${ }^{139}$ Drammeh, Perspectives on New Gambia, 10.

${ }^{140}$ Kora and Darboe, “The Gambia's Electoral Earthquake," 149.

${ }^{141}$ Drammeh, Perspectives on New Gambia, 10.

${ }^{142} \mathrm{~K}$

ora and Darboe, “The Gambia’s Electoral Earthquake,” 149.
} 
were arrested and tortured. This had been an unusually excessive display of violence compared to his previous responses to public protest (it was in the aftermath of this event that Jammeh told Ban Ki-Moon and Amnesty International to 'go to hell'). ${ }^{143}$ Second, in 2015, Jammeh incited ethnic divisions in The Gambia, a country in which ethnic cleavages are not very politically salient and ethnic intermarriages are common. ${ }^{144}$ Jammeh, himself a minority Jola, said that "they" (Ousainou Darboe is a majority Mandika) could never become president, adding that "they" would be wiped out "like flies." ${ }^{45}$ Third, Jammeh sought to activate another cleavage that is not politically salient; between Muslims, comprising $90 \%$ of the population, and Christians, making up most of the remaining 10\%. Renaming the country from the Republic of The Gambia to the Islamic Republic of The Gambia in 2015, was a widely disliked policy. Like the attempt to make ethnicity salient, it served to unite the general public against Jammeh. ${ }^{146}$

The second idiosyncratic reason for the turnover was Barrow's and the opposition's strategic successes. Unlike in previous elections, UDP candidate Barrow was able to forge a coalition of almost all opposition candidates, winning the endorsements of leading politicians and presidential hopefuls like Isatou Touray and Ousainou Darboe. ${ }^{147}$ The opposition also capitalized on newly emerging social media sites in The Gambia, primarily WhatsApp, whose chat groups allowed for independent information to spread, and Facebook, whose live videos allowed illiterate and previously disengaged voters to unite. ${ }^{148}$ This combination of Jammeh's mistakes, and Barrow's and the broader opposition's strategic successes, is important in explaining the defeat of Jammeh's government.

The economic crisis, sparked by the closure of the Senegalese border and consequent decline in debt servicing ability, as well as Jammeh's strategic blunders and the opposition's successes, explain why on December 1, 2016, Jammeh was voted out of office after twenty-two years. A short crisis followed when, after conceding, Jammeh challenged the results of the election, leading to ECOWAS troops being deployed to the Senegal-Gambia border. Barrow had to be sworn in at the Gambian Embassy in Dakar, Senegal's capital, but was able to return to The

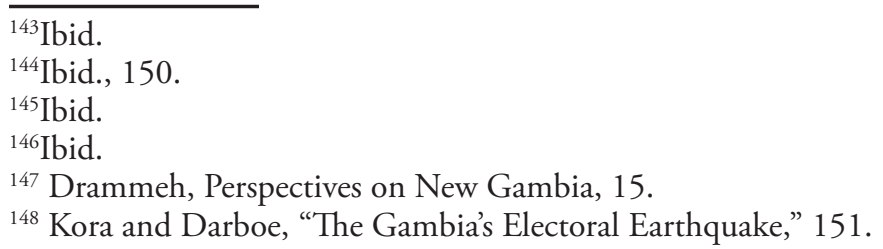


Gambia on January 26, 2017, as President. ${ }^{149}$

\section{SUMMARY}

This case study illustrates the mechanism outlined by Figure 1, while investigating intra-country variation through the analysis of two Gambian instances of electoral authoritarian regime collapse. The heterogeneity in the type of collapse is explored by considering a military coup and an electioninduced collapse. The coup on July 22, 1994, illustrates that in response to a decline in external debt servicing, the government attempted to temporarily raise rent distribution to maintain elite co-optation, but the junior ranks of the military perceived this as a sign of government instability. When combined with idiosyncratic personal grievances, they decided to launch a coup. The election on December 1, 2016, shows that following the closure of The Gambia's border with Senegal, an exogenous economic shock, the percentage of USD-denominated debt and the percentage of GDP composed of commodity rents rose. When combined with Jammeh's idiosyncratic blunders, the economic and political conditions allowed the opposition elites and the general population to mobilize against him and to end twenty-two years of electoral authoritarian rule at the ballot box.

These two instances of electoral authoritarian regime collapse support the mechanism outlined in Figure 1 in two heterogeneous cases. They also illustrate the myriad of unpredictable variables that affect agents' actions, such as Jammeh's nationality-based resentment of his Nigerian superiors in 1994, and his seemingly nonsensical attempt at politicizing ethnicity and religion in 2016. Despite this variation, the model and its findings, as presented in Table 1, are confirmed by the case study.

\section{Conclusion}

Given the large number of electoral authoritarian regimes, and their continued persistence over time, it is essential to understand the causes of their stability. Connecting the literature on domestic political institutions with that on the role of international factors, particularly the international political economy, has shown that debt, and debt servicing ability specifically, affects domestic agents'

${ }^{149}$ Ibid., 155. 
decisions and thereby influences electoral authoritarian stability. A rise in the US interest rate leads to a higher percentage of PPG debt denominated in USD, while a rise in the commodity index increases the percentage of GDP represented by commodity rents. Both of these changes lead to a decline in external debt servicing ability. To respond to this situation, the electoral authoritarian incumbent will attempt to modify the percentage of GDP represented by government expenditure. The way they do so can lead to heterogeneity in the type of electoral authoritarian collapse, with the process being either elite-led or popular mobilization-induced.

This argument contributes to the literature in three main ways. Firstly, it provides clarity about the factors that shape what Svolik called the 'endogenously evolving balance of power' between elites and the incumbent. It shows how international political economic factors, specifically external debt servicing, can influence how elites interact in institutions such as a legislature and in political parties. This relates to previous research by Haggard and Kaufman on the link between economics and elite decisions over the types of democratization in Latin America, ${ }^{150}$ but expands on it by considering the link between international political economic factors and electoral authoritarian stability worldwide. This connection sheds light on some of the 'black box' that is intra-elite dynamics in electoral authoritarian states. Secondly, it links the literature discussing international influences on democratization and democratic regression to electoral authoritarian stability through the lens of economics and debt servicing ability. In an interconnected world, discussions about globalization and international norms are not complete without an understanding of how changes in the Federal Reserve's interest rate, or a change in the ever-fluctuating commodity index, can affect an electoral authoritarian regime's stability. Thirdly, the argument provides new analysis on how the electoral authoritarian leader's decisions about government spending levels can shape elites' and the general population's mobilization against the incumbent. This expands on the literature on the political role of the military, and the intra-elite dynamics and rent distribution patterns that are conducive to a coup. It also places emphasis on the role of popular mobilization, both in and of itself and in terms of its effects on elite mobilization, when discussing collapse by popular uprising or by elections. This expands on our understanding of the types of electoral authoritarian collapse, and the agentic decisions that make them more likely to occur.

\footnotetext{
${ }^{150}$ Stephan Haggard and Robert R. Kaufman, "The Political Economy of Democratic Transitions," Comparative Politics, 29.3 (1997): 263-283.
} 
Further research could elaborate on this work in three ways. Firstly, time series analysis could be incorporated into the study of global, exogenous economic shocks and their longer-term effect on electoral authoritarian stability. Protracted economic crises might introduce new dynamics and critical junctures into the above analysis, and shape domestic agents' decisions in different ways. Secondly, if data about electoral authoritarian regime collapses were available beyond 2010 and closer to the present day, then an expanded time frame would allow for an analysis of discontinuity rates in electoral authoritarian survival over time. Most notably, the end of the Cold War shifted the global political and economic landscape. Thus, considering the effect debt servicing has on electoral authoritarian stability in, for instance, 1960 - 1990 compared to $1990-2020$, would shed further light on the way shifting international factors have affected domestic agents' decisions over time. Finally, this argument has considered how external debt servicing affects electoral authoritarian stability. Further research could consider other international political economic factors that affect electoral authoritarian stability, such as trade or financial flows, as this broader field has much academic and policymaking relevance.

Dawda Jawara might have been surprised to be ousted in a military coup on July 22, 1994, and Adama Barrow might have been surprised to win the election on December 1, 2016. Still, for all the unpredictability and idiosyncrasies of electoral authoritarian regimes, hypotheses can be formulated and tested to understand the causes of their stability - and their collapse.

\section{REFERENCES}

Aggarwal, Vinod K., and Brigitte Granville. "Introduction." In Sovereign Debt: Origins, Crises and Restructuring. Edited by Aggarwal and Granville. London: Royal Institute of International Affairs, 2003.

Albertus, Michael. Autocracy and Redistribution: the Politics of Land Reform.

(New York, NY: Cambridge University Press 2015).

Rabah Arezki, Amadou N. R. Sy, and Thorvaldur Gylfason. Beyond the Curse: Policies to Harness the Power of Natural Resources. (Washington DC: International Monetary Fund, 2011). 
External Debt Servicing and Electoral Authoriatarian Regimes 5 I

Rabah Arezki, Marc Quintyn, Catherine A. Pattillo, and Min Zhu, eds. Commodity Price Volatility and Inclusive Growth in Low-Income Countries. (Washington D.C.: International Monetary Fund, 2012).

Arriola, Leonardo R. Multi-Ethnic Coalitions in Africa: Business Financing of Opposition Election Campaigns. (Cambridge, GBR: Cambridge University Press, 2012).

Atkinson, Anthony Barnes. Public Economics in an Age of Austerity. (New York: Routledge, 2014).

"'Ban Ki-Moon and Amnesty International Can Go to Hell' Says Gambian President Jammeh." Blasting News. May 29, 2016. us.blastingnews.com/world/2016/05/banki-moon-and-amnesty-international-can-go-to-hell-says-gambian-president jammeh-00943399.html

Beck, Linda J. “Senegal's 'Patrimonial Democrats': Incremental Reform and the Obstacles to the Consolidation of Democracy." Canadian Journal of African Studies 31.1 (1997): 1-31.

Boix, Carles, and Milan W. Svolik. "The Foundations of Limited Authoritarian Government: Institutions, Commitment, and Power-Sharing in Dictatorships." The Journal of Politics 75.2 (April 2013): 300-316. https://doi. org/10.1017/S0022381613000029

Callaghy, Thomas. "Africa’s Debt Crisis." Journal of International Affairs 38.1 (1984): 61-79.

Campello, Daniela, and Cesar Zucco. "Presidential Success and the World Economy.” Journal of Politics 78.2 (2016): 589-602. https://doi. org/10.1086/684749.

Campello, Daniela. "The Politics of Financial Booms and Crises: Evidence from Latin America." Comparative Political Studies 47.2 (2014): 260-286. https://doi.org/10.1177/0010414013488539.

Cheeseman, Nic. "African Elections as Vehicles for Change." Journal of Democracy, 21.4 (2010): 139-153. https://doi.org/10.1353/jod.2010.0019

Cheru, Fantu. "Playing Games with African Lives: The G7 Debt Relief Strategy 
and the Politics of Indifference." In Sovereign Debt at the Crossroads: Challenges and Proposals for Resolving the Third World Debt Crisis. Edited by Chris Jochnick and Fraser A. Preston. New York: Oxford University Press, 2006.

Cooke, David, and Arnold Hughes. "The Politics of Economic Recovery: The Gambia's Experience of Structural Adjustment, 1985-94.” The Journal of Commonwealth \& Comparative Politics 35.1 (1997): 93-117. https://doi.org/10.1080/14662049708447740

Drammeh, Seedy. Perspectives on New Gambia. (The Gambia: The Centre for Media and Development Research in Africa, 2018).

Easterly, William. "How Did Heavily Indebted Poor Countries Become Heavily Indebted? Reviewing Two Decades of Debt Relief." World Development 30.10 (2002): 1677-1696.

Edwards, Sebastian and Felipe. Larraín B, eds. Debt, Adjustment and Recovery: Latin America's Prospects for Growth and Development (Oxford, GBR: Basil Blackwell, 1989).

First, Ruth. The Barrel of a Gun: Political Power in Africa and the Coup d'État. (London, GBR: Allen Lane, 1970): 4-5.

“Gambia’s Jammeh Calls Gays 'Vermin', Says to Fight like Mosquitoes.” Reuters, February 18, 2014. www.reuters.com/article/us-gambia homosexuality/gambias-jammeh-calls-gays-vermin-says-to-fight-like-mosquitoes idUSBREA1H1S820140218.

"Gambia’s Jammeh Loses to Adama Barrow in Shock Election Result." BBC News, December 2, 2016. www.bbc.co.uk/news/world-africa-38183906

Gandhi, Jennifer. Political Institutions under Dictatorship. (Cambridge, GBR: Cambridge University Press, 2008).

Gandhi, Jennifer and Adam Przeworski. "Cooperation, Cooptation, and Rebellion Under Dictatorships.” Economics \& Politics, 18.1 (2006): 1-26, https://doi.org/10.1111/j.1468-0343.2006.00160.x. 
Geddes, Barbara, Wright, Joseph and Erica Frantz. How Dictatorships Work: Power, Personalization, and Collapse. Cambridge, UK: Cambridge University Press, 2018).

Gerschewski, Johannes. "The Three Pillars of Stability: Legitimation, Repression, and Co-Optation in Autocratic Regimes." Democratization, 20.1 (2013): 13-38, https://doi.org/10.1080/13510347.2013.738860

Ghanem, Hafez. The Arab Spring Five Years Later. (Washington D.C.: Brookings Institution Press, 2016).

Gutteridge, William. "The Military in African Politics—Success or Failure?" Journal of Contemporary African Studies 1.2 (1982): 241-252.

Grauvogel, Julia and Christian Von Soest. "Claims to Legitimacy Count: Why Sanctions Fail to Instigate Democratisation in Authoritarian Regimes." European Journal of Political Research 53.4 (2014): 635-53. https://doi.org/10.1111/1475-6765.12065.

Greene, Kenneth F. Why Dominant Parties Lose: Mexico's Democratization in Comparative Perspective. Cambridge, UK: Cambridge University Press, 2009.

Haas, Mark L., and David W. Lesch. The Arab Spring: Change and Resistance in the Middle East. (Boulder, Co: Westview Press, 2013).

Haggard, Stephan, and Robert R. Kaufman. "The Political Economy of Democratic Transitions." Comparative Politics 29.3 (1997): 263-283.

Hagmann, Tobias, and Filip Reyntjens. Aid and Authoritarianism in Africa: Development without Democracy. Uppsala, Sweden: Nordiska Afrikainstitutet, 2016.

Howard, Marc Morjé, and Philip G. Roessler. "Liberalizing Electoral Outcomes in Competitive Authoritarian Regimes." American Journal of Political Science 50.2 (2006): 365-381, https://www.jstor.org/stable/3694278

Hughes, Arnold. "'Democratisation' Under the Military in The Gambia: 19942000." Commonwealth \& Comparative Politics 38.3 (2000): 35-52.

Hughes, Arnold, and David Perfect. A Political History of the Gambia, 1816- 
1994. Rochester, NY: University of Rochester Press, 2006.

International Monetary Fund, "The Gambia: Debt Sustainability Analysis.” Approved by Roger Nord, Luis Cubeddo, and John Panzer, March 4, 2015. https://www.imf.org/external/pubs/ft/dsa/pdf/2015/dsacr15104. pdf

Ito, H. and Rodriguez, C.M. "Clamoring for Greenbacks: Explaining the Resurgence of the U.S. Dollar in International Debt.” International Finance (2020). https://doi.org/10.1111/infi.12370

Ito, Takatoshi and Andrew Rose. Commodity Prices and Markets. Chicago, IL: University of Chicago Press, 2011.

Jochnick, Chris and Fraser Preston. Sovereign Debt at the Crossroads: Challenges and Proposals for Resolving the Third World Debt Crisis. New York: Oxford University Press, 2006.

Kaplan, Stephen. Globalization and Austerity Politics in Latin America. New York, NY: Cambridge University Press, 2013.

Keerawella, Gamini, and Rohan Samarajiva. "Sri Lanka in 1994: A Mandate for Peace.” Asian Survey 35.2 (1995): 153-159.

Kora, Sheriff and Momodou N. Darboe. “The Gambia's Electoral Earthquake.” Journal of Democracy 28.2 (2017): 147-156, https://doi.org/10.1353/ jod.2017.0031.

Lemieux, Pierre. The Public Debt Problem: A Comprehensive Guide. New York, NY: Palgrave Macmillan, 2013.

Levitsky, Steven and Lucan Way. Competitive Authoritarianism: Hybrid Regimes after the Cold War. New York, NY: Cambridge University Press, 2010 .

Lewis, Janet I. "How Does Ethnic Rebellion Start?” Comparative Political Studies 50.10 (2017): 1420-1450, https:/doi. org/10.1177/0010414016672235

Lorentzen, Peter L. "Regularizing Rioting: Permitting Public Protest in an 
Authoritarian Regime." Quarterly Journal of Political Science 8.2 (2013). http://dx.doi.org/10.1561/100.00012051

Mainwaring, Scott, and Aníbal S. Pérez Lińan. Democracies and Dictatorships in Latin America: Emergence, Survival, and Fall. (New York, NY: Cambridge University Press, 2013).

McGowan, Patrick. "African Military Coups D’etat, 1956-2001: Frequency, Trends and Distribution." Journal of Modern African Studies 41.3, (2003): 339-370, https://www.jstor.org/stable/3876235.

Riding, Alan. "Rebels in Control of Chad's Capital." The New York Times, December 3, 1990. www.nytimes.com/1990/12/03/world/rebels-in-controlof-chad-s-capital.html

Saine, Abdoulaye. "Post-Coup Politics in the Gambia." Journal of Democracy 13.4 (2002): 167-172.

Svolik, Milan. "Power-Sharing and Leadership Dynamics in Authoritarian Regimes." SSRN Electronic Journal (2008). https://www.jstor.org/stable/25548130

Svolik, Milan. The Politics of Authoritarian Rule. Cambridge: Cambridge University Press, 2012.

Tansey, Oisín. The International Politics of Authoritarian Rule. Oxford: Oxford University Press, 2016.

Tyburski, Michael. "The Resource Curse Reversed? Remittances and Corruption in Mexico.” International Studies Quarterly, 56.2 (2012): 339-350.

Van de Walle, Nicolas. "Conclusion: Democracy Fatigue and the Ghost of Modernization Theory." In Aid and Authoritarianism in Africa: Development Without Democracy. Edited by Tobias Hagmann and Filip Reyntjens. Uppsala, Sweden: Nordiska Afrikainstitutet, 2016.

Weyland, Kurt Gerhard. “The Threat from the Populist Left." Journal of Democracy, 24.3 (2013): 18-32, https://doi.org/10.1353/jod.2013.0045.

Wheeler, Graeme. Sound Practice in Government Debt Management. (The World Bank Group: World Bank Publication, 2004). 
Whitehead, Laurence. The International Dimensions of Democratization: Europe and the Americas. 2nd edition, Oxford, GBR: Oxford University Press, 2001.

Wiseman, John A., and Elizabeth Vidler. "The July 1994 Coup d'État in the Gambia: The End of an Era?" The Round Table 84.333 (1995): 53-65. 